\title{
The Legacy of Wars around the World: Evidence from Military Directors
}

\author{
Jiafu Ana,c, Tinghua Duan ${ }^{b}$, Wenxuan Hou and Xianda Liu ${ }^{a}$ \\ a The University of Edinburgh Business School, 29 Buccleuch Place, Edinburgh, EH8 9JS, UK \\ b IÉSEG School of Management (LEM-CNRS), 1 parvis de La Défense, 92044 Paris, La Défense \\ Cedex, France \\ c University of Portsmouth, Portsmouth, UK
}

\begin{abstract}
This study estimates the effects of wars on countries and firms. We first show immediate negative effects of wars on economic and financial development as well as legal institutions. Using a crosscountry sample of 93,697 firm-year observations, we further argue and show that (i) wars increase the supply of military directors in corporate boards; and (ii) military directors reduce firm performance as measured by Tobin's Q and return on assets (ROA). We interpret these lingering effects as military directors possessing social capital but lacking business expertise. Our results are robust to a matched sample, a lagged difference model, a dynamic general method of moments model and to the control of country, industry and year fixed effects.
\end{abstract}

Keywords: War, Military Directors, Board Directors, Firm Performance 


\section{Introduction}

War brings destruction to society and is often described as "development in reverse" (Collier et al. 2003). A large cross-country literature shows that war-torn regions suffer from a substantial decline in total output, experience slower economic development, and have less persistent growth rates compared to similar but peaceful regions (Barro 1991, Alesina et al. 1996, Alesina and Perotti 1996). While this literature has been enormously influential, it has not yet been able to isolate a clear channel through which war influences economic performance. This paper links war to firm economic performance through directors with military experience. In doing so, we attempt to take a step further in understanding the relationship between, and the mechanism linking, war and its economic consequences.

Understanding how war influences economic development is crucial, because nearly half of all countries in the world have suffered from either external or internal armed conflict in the past few decades (Gleditsch et al. 2002, Harbom and Wallensteen 2007, Blattman and Miguel 2010). People living in war-affected places may be killed, traumatized, or separated from their families. They may also be displaced, prevented from attaining education, and excluded from skilled work. A vibrant stream of research documents the negative effects of war on later-life income, health, and education. Yet, these negative outcomes may have implications on the wider society. In this paper, we aim to provide evidence of such implications.

To do so, we merge several datasets on war, board directors, and firm performance during 1999-2016, from 119 countries, and examine whether directors with military experience influence firm performance. Particularly, the war dataset, Correlates of War Data (COW), contains information on the involved parties, durations, and casualties of wars during 1816-2007. We merge these data with information on board directors from BoardEx, a database that contains information on directors' backgrounds, genders, and tenures, as well as board sizes, and shares of independent directors. Finally, we combine this dataset with firm performance measures, such as 
Tobin's Q and return on assets (ROA), market capitalization, leverage, fixed assets (property, plant and equipment, henceforth PPE), and sales, from Thomson Reuters' WorldScope. We then assess the association between military directors and firm outcomes by regressing measures of firm on the share of military directors on the board, while accounting for observable covariates and some country-level unobservable factors.

Theories on war and its legacy on individuals' behaviours suggest that military directors from war-affected regions can influence firm performance in both directions. On the one hand, directors with military experience can incorporate strict disciplines in monitoring firms' managers, when necessary, and thus improve the corporate governance quality (Benmelech and Frydman 2015). The reduction in agency costs due to improved governance can subsequently translate into good firm performance. Further, directors with military experience can improve the efficiency of the board in general because war, or conflict in general, can foster cooperative and prosocial behaviours among the affected individuals (Bauer et al. 2016). The increased board efficiency can improve firm performance through monitoring and/or advising mechanisms.

On the other hand, military directors may affect firm performance negatively because of the interruption to human capital and work experience accumulation when in the army (Angrist 1990, 1998, Angrist and Krueger 1994). Lack of education and experience may result in poor governance and advice from military directors, causing firm performance to decline. In addition, the effects of psychological trauma, such as malaise or less engagement with other people, may cause problems in board communication and coordination, thus lowering the efficiency of the board (Ehlers and Clark 2000, Galovski and Lyons 2004) and, in turn, firm performance.

Our empirical results can be summarized as follows. Firstly, as motivating analyses, we show that war-torn countries are correlated with slower growth in gross domestic product (GDP) per capita, a smaller amount of private credit, and a poorer legal environment as proxied by the 
rule of law index from the International Country Risk Guide (ICRG) database ${ }^{1}$. More importantly, we show that countries that have experienced wars are associated with more military directors and more firms with military directors, and this relationship holds both at the extensive margin (proxied by the number of wars in a country) and the intensive margin of war (measured by the number of casualties of and the number of years at war).

Next, using ordinary least squares (OLS) regressions, we discover that the share of military directors is strongly, negatively correlated with a firm's performance as proxied by Tobin's Q. In order to isolate the effects of military directors on firm performance, we saturate the model by including a large set of covariates, including market capitalization, leverage, PPE, sales growth, board size, board independence, the gender ratio of the board, the average tenure of the board members, and CEO duality, as well as country, industry and year fixed effects to control for unobservable time-invariant country and industry traits, and global events in any specific year. The estimated effects of military directors on firm performance, assuming causality, is non-trivial. Consider column (1) in Table 6, where a one-standard-deviation increase in the share of military directors $(0.05)$ is associated with a $0.02(=0.05 * 0.4119)$ decrease in a firm's Tobin's Q, equivalent to $1 \%$ of the sample average. The estimated effect on the extensive margin of military directors is also striking. Using a dichotomous variable that equals one if a firm has at least one military director and zero otherwise as our key independent variable, we uncover that the relationship between military directors and firm performance, measured either by Tobin's Q or ROA, is both significant and negative. The economic size of the estimates is large. For example, an average firm with at least one military director on the board has a Tobin's Q that is 0.06 points lower than an identical firm without a military director. To provide a reference, this is $3 \%$ of the sample mean. When using ROA as a proxy for firm performance, we find qualitatively similar results.

\footnotetext{
${ }^{1}$ We justify the use of these variables in the data section.
} 
These empirical patterns suggest that the negative impacts of military directors (mainly via the advising mechanism) on firm performance outweigh the positive (largely through the monitoring channel) in our sample. We proposal several explanations. First, board members may generally exert more efforts in advising than in monitoring. Indeed, as stressed in Güner, Malmendier and Tate (2008), board directors spend a significantly greater portion of their time advising than they do monitoring the managers (Adams and Ferreira 2007). Therefore, even if military experience changed directors' monitoring and advising behaviours to the same extent, we would still observe the advising (negative) channel of military directors as dominating the monitoring (positive) mechanism, resulting in a net negative impact on firm performance. Second, the improved monitoring of firm managers due to a high level of integrity applied by military directors may again stymie effective advising, since managers (facing heightened oversight) may be unwilling to disclose inside information to directors. Without effective and useful information from the management, directors may provide uninformed advice and make inferior business decisions, hence destroying firm value (Adams and Ferreira 2007, Harris and Raviv 2006, Duchin, Matsusaka and Ozbas 2010). This puts a dynamic factor on the negative impact military directors have on firm performance, such that we observe a net negative effect in our empirical analyses. Lastly, since the previous two explanations are not mutually exclusive, the net negative impact may be a result of both mechanisms at play: managers spend less time monitoring managers, and if they do, they stymie the information flow from managers and consequently give uninformed advice and make inferior business decisions. While our data do not allow us to differentiate among these explanations, they nonetheless provide some suggestive evidence on the possible channels that may be underlying the empirical patterns.

There may be unobservable omitted variables correlated with both firm performance and the number of military directors that could potentially be driving our results. For example, economically successful countries with many successful firms may also be able to wage more wars and therefore have more military directors. Similarly, directors with military experience may 
automatically sort themselves into industries that have high profit margins, such as arms and ammunitions. To mitigate this concern, we add an array of fixed effects at both the national and industry levels. In addition, we control for time-specific shocks to further saturate the model. Note that the empirical patterns documented here should still be interpreted with caution because we are unable to account for time-variant, unobservable factors.

Another important concern arises from potential reverse causality. That is, firms with poorer performance may be more likely to appoint military directors in order to improve performance. Indeed, several studies document that directors with military experience serve as better monitors of firms' managers and therefore increase firm performance (e.g., Benmelech and Frydman 2015). We conduct two tests to address this concern. First, we redo our baseline analyses with a lagged first difference (LFD) model, where we regress the change in the measures of firm performance in year $t$ on the change in the military director variables in year $t-1$. We find that our results for Tobin's Q become stronger both quantitatively and qualitatively. The results for ROA, however, become imprecisely estimated. One possible reason is that, due to a lack of business experience, military directors may put more emphasis on firms' short-run profits at the expense of their long-term growth potential. Therefore, we observe little difference in ROA between firms with more versus fewer military directors, but a large difference in Tobin's Q, a measure of a firm's future growth. Another possible explanation is the reduced sample size. Using the LDF model, our sample size decreases by about $40 \%$, which results in a larger standard error. Note that it is difficult to disentangle which explanation drives our results, or whether it is both. Thus, we seek further evidence from a two-step dynamic general method of moments (GMM) model.

We re-run our analyses using a two-step dynamic GMM model, which potentially allows us to circumvent both omitted variables and reverse causality issues (Blundell and Bond 1998, Judson and Owen 1999). In particular, we treat all dependent variables as endogenous and instrument them using their lagged values in years $t-3$ and $t-4$, under the assumption that these 
lagged values influence the outcomes variables in year $t$ only though their values in $t-1$ (Bun and Windmeijer 2010). The estimates from the GMM model confirm our main results. We find that military directors significantly reduce firm performance as proxied by either Tobin's Q or ROA. This is in line with the second explanation that the imprecise estimates for firm ROA from the LFD model are due to a huge reduction in sample size. We, nevertheless, advise readers to take caution when interpreting our results.

It is also possible that the covariates that we are currently controlling for may have nonlinear relationships with the measures of firm performance and the variables related to military directors, such as the directors' genders and tenures and the board size. We therefore perform a propensity score matching (PSM) analysis to tackle this issue. Specifically, we first match firms on market capitalization, leverage, PPE, sales growth, board size, board independence ratio, directors' gender, directors' tenure and CEO duality, and then we conduct simple mean tests on the treated and control groups. We discover that the results are qualitatively identical to the OLS estimates, providing reassurance about our analyses.

This study relates to the literature on the economic legacies of wars. Cerra and Saxena (2008) find that GDP growth rates decline by 6\% immediately after a civil war. Quantitative case studies, such as Abadie and Gardeazabal (2003) and Justino and Verwimp (2006), show that economic growth decreases significantly following armed conflicts, a pattern consistent with the cross-country evidence. Our paper complements these macro studies from a micro-economic perspective. We show that war hinders economic performance through the influence of military directors in war-affected areas. This suggests that the influence of wars on the economy goes beyond the direct effects on physical and human capital.

This paper adds to a large literature on the link between board directors' experience and various firm policies and outcomes. Güner, Malmendier and Tate (2008) document that board directors with experience in commercial banks increase firms' access to external financing, and 
directors with investment bank experience help firms raise larger amounts of credit through debt issuance. Giannetti, Liao and $\mathrm{Yu}$ (2015) show that directors with business experience in a foreign country can increase a firm's governance quality and thus promote firm growth. Masulis, Wang and Xie (2012) demonstrate that firms with foreign independent directors have better cross-border acquisitions outcomes when the targets are based in their home countries. We contribute to this line of research by presenting evidence that directors with military experience stymie firm growth due to their lack of business experience. In a related strand of literature, Benmelech and Frydman (2015) document that firms led by chief executives with military experience tend to perform better during economic downturns (An et al. 2019a). We complement this study by showing the negative impacts imposed by directors with military experience. While Benmelech and Frydman's (2015) study emphasizes the positive traits of veterans, including being ethnic and conservative, we stress their other, important side, i.e., their lack of business experience.

This study also contributes to the literature on the negative impacts of war on human capital. Alderman, Hoddinott and Kinsey (2006) document that, in Zimbabwe, young children who experience war-related malnutrition become stunted as adults, with likely adverse effects on their lifetime labour productivity. Bundervoet, Verwimp and Akresh (2009) show that children from a war-torn region have considerably lower height-for-age ratios than otherwise identical children. In a related study, Shemyakina (2006) discovers that adolescent Tajik girls who have seen their homes destroyed in the civil war have a lower probability to get secondary education, which may have a negative influence on their future wages and life chances. Our study sheds light on this literature by documenting that, for those who have found their way into skilled employment, war experiences can still have an adverse impact on their performance.

Lastly, our study relates to the literature on post-war economic recovery. Studies that examine the consequences of U.S. bombing on post-war performance find that places heavily affected by the bombing quickly recovered to the pre-war trends, in terms of population, in both 
Japan and Germany (Davis and Weinstein 2002, Brakman, Garretsen and Schramm 2004). In Vietnam, Miguel and Roland (2006) find a similarly rapid recovery of the local population after bombing. These pieces of evidence are consistent with the predictions of the neoclassical model, namely, rapid recovery to pre-war equilibrium levels. Our paper provides the contrary evidence that war can have lasting impacts through human capital. Even wars that happened nearly 200 years ago can still exert an adverse influence on military directors from the war-affected regions.

The rest of the paper is organized as follows. Section 2 discusses the related literature, section 3 introduces the data and methodology, and section 4 presents the country-level outcomes. Section 5 discusses the effects of military directors on firm-level performance, section 6 conducts robustness checks, and section 7 presents results on firm leverage. Section 8 discusses some potential future research areas and concludes.

\section{Consequences of warfare}

Since 1960, warfare has afflicted over half of all nations, imposing severe destruction on physical, human and social capital, and persistent adverse effects on growth (e.g., Blattman and Miguel 2010, Bauer et al. 2016). While war is key to many countries' development, it has been on the periphery of finance and economic research for a very long time. The past two decades have witnessed an overdue explosion of research on war's consequences. This section summarizes this literature, identifies the gaps, and provides the motivation for the current study.

\subsection{Physical destruction}

The most staggering impressions of war are those of physical destructions. Cerra and Saxena (2008) find that such destruction can cost as much as $6 \%$ of a country's total output. However, a growing empirical literature shows that the destroyed physical capital can quickly be recovered after a war ends (Przeworski et al. 2000). This is largely consistent with the prediction from the neoclassical model, which stresses that a one-time shock has zero impact on the equilibrium level of growth 
(Lucas 1988, Mankiw, Romer and Weil 1992). Davis and Weinstein (2002) examine the bombing of Japan during the second World War and find that areas that were heavily bombed are indistinguishable in terms of physical capital (measured by population size) from places that were untouched during the bombing, only 20 to 25 years after the war. Brakman, Garretsen and Schramn (2004) and Miguel and Roland (2006) find similar results in Germany and Vietnam after bombing.

Nevertheless, there are reasons to apply caution in generalizing these results. First, there may be selection bias in the cases of bombing, with places that have recovered having good data and those that have not dropping out of sample. Second, bombing itself may not be random and is in essence different from other forms of physical destruction, such that the authors may be capturing the effects of other unobservable characteristics of bombing. Indeed, after taking all forms of civil war into account, Cerra and Saxena (2008) show that, although economic performance rebounds most quickly in the case of wars, as compared to other forms of crises (e.g., banking and currency crises), only half of the fall is recovered. This leaves room for further research into the persistent adverse effects of wars.

\subsection{Human capital}

Another destructive legacy of war is the erosion of human capital. In 1999 alone, nearly 269,000 deaths and 8.44 million disability-adjusted life years (DALYs) were attributed to wars. Counting the cumulative effects of wars between 1991 and 1997, these estimates are tripled (Ghobarah, Huth and Russett 2003). While the literature seems to have reached a consensus on the severity of war's impact on human capital, there is still an open debate on how long these adverse effects last. On the one hand, Miguel and Roland (2006) find that, 25 years after the Vietnam War, local living standards and human capital tend to converge quickly across regions. On the other hand, evidence from sub-Saharan Africa shows that such negative effects persist many decades after war. For example, Alderman, Hoddinott and Kinsey (2006) show that war-related malnutrition in 
Zimbabwe leads young children to be significantly shorter as adults, harming their productivity. In central Asia, Shemyakina (2006) finds that Tajik girls who did not receive secondary education due to the civil war have subsequently earned significantly lower waes. A related literature on the impact of conscription on young people reveals similar adverse effects (e.g., Angrist 1990, 1998, Angrist and Krueger 1994).

It is important to note that this literature is limited in its ability to credibly estimate the aggregate nation-wide economic consequences of war destructions (Blattman and Miguel 2010). Because even largely peaceful regions close to the combat field are adversely affected by war disruption, the estimates presented in these studies are likely to underestimate the true effect.

\subsection{Social capital and institutions}

The impact of war on society and institutions are arguably the most important and widely debated of all war consequences. A sizable literature argues that wars can promote governments' legitimacy. For instance, in the three cases of bombings discussed previously, the governments rallied their citizens to fight foreign enemies and thereby strengthened state institutions (Miguel and Roland 2006, Davis and Weinstein 2002, Brakman, Garretsen and Schramn 2004). Cross-country studies find similar evidence that countries have more stable peace and stronger state institutions after an outright military victory for one fighting side (Fortna 2004, Toft, 2003). As Blattman and Miguel (2010) point out, this result may not be generalizable to civil wars. In a civil war, both the winning and losing sides often co-exist in a society, potentially deepening divisions politically and socially. Further, civil wars sometimes create a culture of violence in the society. Miguel, Saiegh and Satyanath (2008) show that European football league players with more exposure to civil wars commit substantially more fouls than otherwise similar players with less exposure.

In addition, a vibrant body of literature documents that exposure to wars promotes prosocial behaviour, whereby people behave more cooperatively and altruistically. Evidence across the globe shows that individuals with more exposure to war-related conflict are more likely to join 
local social and civic groups, take on leadership roles in their communities, and engage in altruistic giving (Bellows and Miguel 2006, Blattman 2009, Bowles 2008). This effect differs little across different types of violence, populations, ages and studies with different empirical strategies (Bellows and Miguel 2006, Blattman 2009, Voors et al. 2012). In addition, the impact of war on prosocial behaviour appears to be very persistent through time. Bauer et al. (2016) show evidence that the effect of violence on cooperative behaviour can last for many years after war, and sometimes even becomes more pronounced over time. Finally, several studies show that war exposure affects in-group prosocial behaviour the most, i.e. among members of one's own village or ethnic group (Bateson 2012, Bauer et al. 2014). However, as these studies rarely define outgroups consistently, the evidence remains speculative.

\subsection{Theories and hypotheses}

While there are many macro-level studies on the economic consequences of war, micro-analyses on how war influences development and through what channels are rare. The existing ones are predominantly based on household survey data and may therefore suffer from self-reporting bias (Deininger 2003a, Bellows and Miguel 2006). In this paper, we draw our predictions based on agency theory and focus on a specific channel, i.e. military directors, through which war affects development.

Agency theory is a particularly useful framework in which to study the link between board characteristics and firm outcomes, since it addresses causes and consequences of misaligned interests between shareholders and managers (Boyd 1994). The board of directors, representing the interests of the shareholders, monitors and advises the firm management so that it will act in those interests (Fama and Jensen 1983). Without such monitoring and advising, a CEO with minimal equity ownership may focus on pursuing her/his own wealth rather than the good of the firm, such as through engineering a higher-than-optimal fixed salary (Walsh and Seward 1990), making value-destroying takeovers, i.e. empire building (Jensen and Meckling 1976, Jensen 1986, 
1993), or designing entrenchment strategies so as to stay in power (Berger, Ofek and Yermack 1997). Boards of directors can alleviate such agency problems through the "decision control" functions. In particular, as emphasized in Fama and Jensen (1983), the board of directors provides advice on major business strategies to be initiated by the firm management, and then monitor the implementation process and perform evaluations of firm performance. In doing so, the board can better resolve and align different interests between shareholders and the top management team (Mizruchi 1983, Walsh and Seward 1990), thus increasing firm value.

However, the extent to which the board of directors can alleviate agency problems depends critically on the directors' willingness and incentives to monitor, and their ability to provide valuecreating advice (Franke 2001, Benmelech and Frydman 2015, Agrawal and Chadha 2005, Defond, Hann and $\mathrm{Hu}$ 2005). We argue that directors with military experience can affect firm growth in two opposing ways, generating an empirical question worth exploring. On the one hand, military directors can enhance firm value, since their experience in the army allows them to apply a high level of integrity in monitoring firms' executives (Franke 2001, Benmelech and Frydman 2015). On the other hand, directors with military experience can inhibit firm growth because the interruption of human capital accumulation when in the army (Griliches and Mason 1972, Angrist 1990, 1998, Angrist and Krueger 1994) and their lack of business experience and networks can make them inefficient in the advising role (An et al. 2019b). In sum, board directors with military experience may be a double-edged sword for firm growth, playing an advantageous monitoring role but a disadvantageous advising role vis-à-vis their peers. In the following, we first discuss the role of directors in shaping firm performance, and then develop our hypotheses on how military experience may influence that relationship.

\subsubsection{Board directors and firm performance}

Agency theory argues that firm executives often pursue business strategies that benefit themselves at the expense of the shareholders' interests due to misaligned preferences between managers and 
shareholders (Holmstrom 1979, Shleifer and Vishny 1997). The misaligned preferences, or "moral hazard" as labelled by economists, can take many forms, such as insufficient effort (Bertrand and Mullainathan 2003), extravagant investments (Jensen 1988[this year not in reference list]), entrenchment strategies (Shleifer and Vishny 1989 [this year not in ref list]), and self-dealing (Burrough and Helyar 1990, Yermack 2004), all of which are found to decrease firm value (e.g., Tirole 2006).

The board of directors is meant to mitigate these moral hazard concerns. In principle, the board of directors monitors executives on behalf of the shareholders and is in charge of approving major business strategies, setting management's compensation, and offering advice and connections to executives (Fama and Jensen 1983, Hermalin and Weisbach 1991). In practice, however, the evidence on the effectiveness of board directors in monitoring and advising management is often mixed. One stream of literature argues that corporate boards are merely window dressing and add no value to shareholder wealth (e.g., Helland and Sykuta 2004, Bebchuk and Fried 2005). For example, board members are often captured by the firm management or are pursuing strategies that maximize their personal interests (e.g., perks, social ties, future career benefits) at the expense of the shareholders (Jensen 1993, Shivdasani and Yermack 1999, Bebchuk and Fried 2005).

Other scholars, on the other hand, emphasize and provide evidence on the positive impact of boards of directors on firm value (e.g., Dahya and McConnell 2007, Lin, Schmid and Xuan 2018, Lin, Officer and Zou 2011). Chhaochharia and Grinstein (2007), for example, show that an improvement in board independence following the 2002 governance reform in the U.S. had a positive effect on firm value. Similarly, Lin et al. (2019) find that better-aligned interests between directors and shareholders due to a change in directors' and officers' insurance policies lead to an increase in firm value. Relatedly, several studies document that an increase in directors' financial expertise and accounting knowledge is associated with higher firm value. In sum, the board of directors is a key factor determining firm performance, and its effectiveness in shaping firm 
performance critically depends on board members' integrity in monitoring, and experience and knowledge in advising the management team.

\subsubsection{The role of military experience}

The board of directors can influence firm performance through its monitoring and advising of the management. In this section, we argue that directors' military experience, which instils a high level of integrity and in the meantime crowds out business experience and knowledge, affects firm performance in two opposing ways.

On the one hand, military directors can enhance firm value, since their experience in the army allows them to apply a high level of integrity to monitoring the firm's executives and thus improve the quality of corporate governance (Franke 2001, Benmelech and Frydman 2015). The reduction in agency costs due to improved governance can in turn promote firm growth. Indeed, increasing the level of board members' integrity and independence (hence enabling them to stand up to the firm managers) has been a top priority of many corporate governance reforms, such as the Sarbanes-Oxley Act of 2002 (SOX), and regulations required by various security exchanges. Scholarly research also lends support to this argument. For example, Adams and Ferreira (2007), Harris and Raviv (2006) and Duchin, Matsusaka and Ozbas (2010) suggest that, when information costs are low, a higher level of monitoring due to an exogenous increase in board integrity and independence results in greater firm valuation and better outcomes. Since military experience instils a high level of integrity in board directors, we expect a positive association between military directors and firm outcome. This leads to the following hypothesis:

Hypothesis (H1a) Board directors with military experience have a positive impact on firm value. 
On the other hand, directors with military experience can inhibit firm growth because the interruption of human capital accumulation when in the army (Griliches and Mason 1972, Angrist 1990, 1998, Angrist and Krueger 1994) and the lack of business experience and knowledge can lead to uninformed business advice (An et al. 2019a). As stressed in Fama and Jensen (1983), boards of directors add value to firms by advising and monitoring the managers. In particular, board directors are in charge of major business decisions such as the disposal of assets, investments, acquisitions, tender offers by acquirers, executive compensation and risk management (Tirole 2006). A lack of business experience and knowledge, therefore, can lead to uninformed business decisions, hence destroying firm value. Ahern and Dittmar (2012), for example, document that younger and less experienced boards that have resulted from a regulatory change in Norway have caused a substantial drop in firm stock prices. They further show that the negative impact on firm value can last many years, due to inferior business strategies including undertaking unjustified acquisitions and increasing firm leverage. Conversely, Agrawal and Chadha (2005) and Defond, Hann and $\mathrm{Hu}$ (2005) find positive links between board directors' financial literacy and the firm's share price. Similarly, Giannetti, Liao and Yu (2015) document an increase in firm performance following the hiring of board members with management and business skills. Since being in the army causes an interruption to human capital and business experience and knowledge accumulation, we expect a negative association between military directors and firm outcomes, leading to the following competing hypothesis:

Hypothesis (H1b) Board directors with military experience have a negative impact on firm value.

This paper is distinct in three important ways from previous research. First, we deviate from the macro-level analyses and instead focus on one specific channel that links war to development, i.e. board directors. While the existing small amount of micro-level evidence largely relies on 
household survey data, Collier and Duponchel (2012) argue that the key mechanism through which war affects development is probably through firms. Second, previous micro-level analyses are limited to a single country (Deininger 2003b, Bellows and Miguel 2006, Collier and Duponchel 2012), and may therefore lack generalizability to other countries. This paper uses a global sample of 93,697 firm-year observations to provide a more generalizable estimate. Lastly, we contribute to the understanding of war's impact on firms by providing evidence on a new channel that links war to firm growth. Collier and Duponchel (2012) demonstrate that firms' income and size are affected by the disruption to production and reduction in consumer income. We show that war also influences firm development through the board of directors.

\section{Data and methodology}

In this section, we firstly define the key data that we use to evaluate the relationships between war and various country-level outcomes as well as firm performance. Appendix 1 gives detailed variable definitions and data sources, and Table 1 provides summary statistics.

\subsection{Data and sample}

We obtain data on wars from COW, which provides information on wars from 1816-2007 around the world. We use the data on intra- and inter-state wars that ended before 1945, although the dataset also contains information on extra- and non-state wars ${ }^{2}$. This results in a sample that includes 80 countries. Figure 1 shows a visualization of the number of wars by country in our sample.

Our data on country-level economic, financial, and legal development are obtained from the World Bank Open Data program. In particular, we measure a country's financial development by the total amount of credit channeled into the private sector, scaled by GDP (Private Credit to

\footnotetext{
${ }^{2}$ Extra-state wars take place between a state(s) and a non-state entity outside the borders of the state, while non-state wars are between or among non-state entities. The effects of these wars are difficult to assign to specific countries since the involved parties typically do not possess a state status.
} 
GDP), an indicator commonly found in the literature (e.g., Djankov, McLiesh and Shleifer 2007, Djankov et al. 2008). The quality of legal institutions is proxied by the rule of law index (Rule of Law) from the ICRG database. Several influential studies use the same measure (e.g., Knack and Keefer 1997, Kesternich and Schnitzer 2010). After merging the war dataset with these countrylevel variables, the number of countries in our sample ranges from 61 to 71.

At the country level, we construct two variables that measure the prevalence of military directors in corporate boards. The first variable measures the total number of directors with military experience (MilDirNum), while the second measures the total number of firms that have at least one military director sitting on their board (MiliFirm). We also provide a visualization of the total number of firms with at least one military director by country in Figure 2. If we conceptually overlay Figures 1 and 2, we can see that places with a high intensity of wars also have a larger number of firms with military directors.

\section{[Insert Figure 1 and Figure 2 here]}

At the firm level, we obtain employment information on board directors from the BoardEx Individual Profile of Employment database. The database contains various pieces of employment information for a global sample of corporate executives. We first identify 15,582 records of military employment for 9,455 unique executives, and then match these executives into corporate boards. In total, we successfully match 2,642 directors with military experience into 17,519 firms globally. Since there might be heterogeneous effects of military directors on firm policy and performance due to the different roles they played in the armed forces, we further differentiate between military directors with frontline experience and others. BoardEx provides us with the role title held by the director when in the military, which enables this.

In Appendix 2, we present the distribution of observations by country. To increase the power of our main tests, we include all sample countries that have at least one matched firm. To ensure that our results are not driven by countries with fewer observations, we redo all of our 
analyses using only those countries with at least 30 matched firms. Our results are similar both quantitatively and qualitatively ${ }^{3}$.

We also obtain data on other board characteristics, namely Board Size, Board Independence, Gender, Average Time on Board, CEO Duality, Foreign Background, Financial Expertise, and Legal Expertise, from BoardEx. We complement this with firm-level data obtained from WorldScope, a dataset constructed by Thomson Reuters, namely Tobin's Q, ROA, Market Capitalization, Leverage, PPE, and Sales Growth. Detailed variable definitions are provided in Appendix 1.

[Insert Table 1 here]

\subsection{Research design}

We use cross-country comparisons of the intensity of war and modern economic, financial and legal development, as well as the prevalence of military directors, to provide motivation for our examination of the impact of wars on firm performance. We begin with the following regression specification:

$$
\operatorname{Marco}_{c, t}=\alpha+\beta W \text { ar Indicator } \text { Int }+\Gamma X_{c, t}^{\prime}+\delta_{c}+\Upsilon_{t}+\varepsilon_{c, t}
$$

where the dependent variable Marco $_{c, t}$ is either GDP Per Capita Growth, Private Credit to GDP, Rule of Law, MilDirNum, or MiliFirm in country $c$ in year t. Private Credit to GDP is the total amount of credit channeled into the private sector scaled by GDP and has been widely used in the literature (Djankov, McLiesh and Shleifer 2007, Djankov et al. 2008). Rule of Law measures the quality of a country's legal system and is obtained from the ICRG database (Knack and Keefer 1997, Kesternich and Schnitzer 2010). MilDirNum measures the total number of directors with military experience. MiliFirm measures the total number of firms that have at least one military director sitting on their board. Our key variable of interest is the War Indicator ${ }_{c, t}$, which is either War

\footnotetext{
${ }^{3}$ Due to space constraints, we do not present these results here, but submit them to the referees. Results from this alternative sample are available upon request.
} 
Involve (Dummy), an indicator that equals one if country $c$ experienced war in year $t$ and zero otherwise, or $W$ ar Involve (Number), the total number of wars country $c$ has been through in year $t$. $X_{c, t}^{\prime}$ is a vector of country-level control variables that include No. of Soldier Deaths, Log (GDP per capita) and Log (Population). No. of Soldier Deaths is the average number of soldier deaths in a year. $\log$ (GDP per capita) and $\log$ (Population) are the natural logarithms of the GDP per capita and the population in a country, respectively. $\delta_{c}$ and $Y_{t}$ are country and year fixed effects. We cluster our standard errors at the country level.

We assess the relationship between the presence of military directors on the corporate board and firm performance using the following regression specification:

$$
\text { Firm Performance }_{i, j, c, t}=\alpha+\beta \text { Military }_{i, j, c . t}+\Phi Z_{i, j, c, t}^{\prime}+\gamma_{j}+\delta_{c}+\Upsilon_{t}+\varepsilon_{i, j, c, t}
$$

where the dependent variable Firm Performance ${ }_{i, j, c, t}$ is either the Tobin's $Q$ or $R O A$ of firm $i$ in industry $j$, country $c$, and year $t$. Our key variable of interest, Military $y_{i, j, c . t}$ is either Military Director Ratio, a measure calculated as the number of military directors on the board over the board size, or Military Director Dummy, an indicator that equals one if a firm has at least one military director sitting on its board and zero otherwise. $Z_{i, j, c, t}^{\prime}$ is a vector of firm-level control variables, namely Market Capitalization, Leverage, PPE, Sales Growth, Board Size, Board Independence, Gender, Average Time on Board, and CEO Duality. Market Capitalization is the natural logarithm of the market value of a firm. Leverage is the ratio of a firm's total liabilities to total assets. PPE is calculated as the ratio of property, plant, and equipment to total assets. Sales Growth is the three-year average growth rate of the net sales. Board Size is the total number of directors on the board. Board Independence is measured as the number of non-executive directors divided by the board size. Gender is the number of male directors divided by the board size. Average Time on Board measures the average tenure of the board directors of a firm. CEO Duality is an indicator that equals one if a firm's CEO is also the chairman of the board and zero otherwise. $\gamma_{j}, \delta_{c}$, and $\Upsilon_{t}$ are industry, 
country and year fixed effects, respectively. In all regressions, we cluster our standard errors at the country level.

\section{War and country-level outcomes}

\subsection{Economic growth, financial development and legal institutions}

In this section, we start by discussing the results of our motivating regressions. Wars damage human and physical capital (Collier et al. 2003). A large literature shows that war-torn regions experience a substantial decline in total output, experience slower economic development, and have less persistent growth rates compared to similar but peaceful regions (Barro 1991, Alesina et al. 1996, Alesina and Perotti 1996). In Table 2, we present the results on the relationship between war and country-level economic growth, while controlling for the level of economic development, population density, and country and year fixed effects. We find that war is significantly, negatively associated with economic growth as measured by the GDP per capita growth rate, and this relationship holds both at the intensive (War Involve (Number)) and extensive margin (War Involve (Dummy)). The economic magnitude of the estimates is large. For example, consider the estimate from column (3) in Table 2, where we include both country and year fixed effects to control for the various time-invariant confounders and year-specific shocks. A one-standard-deviation increase in War Involve (Number) (0.41) is associated with a $0.49(=1.21 * 0.41)$ increase in GDP Per Capita Growth, which accounts for $20 \%$ of the sample mean (2.38). Similarly, on the extensive margin, consider the estimate from column (6) in Table 2. The coefficient implies that countries that have experienced war have a lower growth rate than otherwise similar countries that have not by 1.86 points, equivalent to $78 \%$ of the sample mean.

\section{[Insert Table 2 here]}

We find similar results on financial development and legal institutions. In particular, Table 3 shows that wars, either measured by $W$ ar Involve (Number) or $W$ ar Involve (Dummy), are significantly, 
negatively associated with financial development (Private Credit to GDP). The economic magnitude is non-trivial. Consider, for example, column (3) in Table 3. The estimate implies that a standard deviation increase in $W$ ar Involve (Number) is associated with a $1.46(=0.41 * 3.59)$ percentage point decrease in Private Credit to GDP, which equals $4.5 \%$ of the sample mean (32.76). As emphasized by King and Levine (1993), Levine (2005) and Popov (2018), financial development is crucial for promoting economic growth. Therefore, the negative relationship between wars and financial development warrants further research on the mechanism linking the two, i.e., military directors.

\section{[nsert Table 3 here]}

We present results on the relationship between wars and the quality of legal institutions in Table 4. In a series of influential studies, La Porta et al. (1998) show that a country's legal environment is important in determining its economic outcomes. Better creditor rights protection, contract enforcement and private property protection, for example, are found to promote a country's economic and financial development. We find that wars are negatively, significantly related to the quality of the legal system as measured by Rule of Law, an indicator that ranges from 0 to 6 , with higher values indicating better legal environments. The economic magnitude is large. For example, take the coefficients from column (3) in Table 4. The estimate suggests that a onestandard-deviation increase in $W$ ar Involve (Number) is related to a $0.16\left(=0.405^{*} 0.3925\right)$ decrease in the Rule of Law index. This decrease is equal to $4.5 \%$ of the sample mean (3.58). The estimate from the extensive margin of war implies a similar change in the Rule of Law index.

\section{[Insert Table 4 here]}

\subsection{War and military directors}

The results from Tables 2-4 reveal that wars are associated with worse economic growth and financial development and poorer legal environments, and the economic magnitudes are large. Therefore, it is important to study the underlying mechanisms that link the two, for example, via 
the lens of military directors. Before discussing the main results for the effect of military directors on firm growth, however, it is critical to empirically demonstrate that wars are indeed related to a higher prevalence of military directors sitting on corporate boards. From Table 1, we can see that the number of firms with at least one military director on their board (MiliFirm) has substantial variation across countries. The standard deviation of MiliFirm is 102 , which is about five times the sample mean (20.90). We observe a similar distribution in the number of military directors. In Figure 2, we also present a visualization of the distribution of firms with military directors across countries.

In Table 5, we present the results of regressing either the total number of military directors in a country (MilDirNum) or the total number of firms with at least one military director sitting on their board (MiliFirm) on various measures of war intensity. We find that wars are indeed significantly, positively associated with both variables for military directors, and the economic size is large. Consider column (1) in Table 5, for example. The estimate implies that a one-standarddeviation increase in the total number of years for which a country is at war (Total War (Year)) (6.19) is associated with an increase in the number of military directors of $167.63(=6.19 * 27.08)$, which is six times higher than the sample mean (23.86). For another example, consider column (4) in Table 5. The coefficient on Total War (Number), a variable that equals the total number of wars that a country has experienced, suggests that a one-standard-deviation increase (4.60) is associated with an increase in the number of firms with at least one military director, of $155.25(=33.75 * 4.60)$, which is also about six times higher than the sample mean (20.92).

[nsert Table 5 here]

\section{Military directors and firm performance}

\subsection{Baseline results}


We next present our baseline results on the relationship between military directors and firm performance, in Table 6. From our OLS estimations, we find that military directors are negatively, significantly associated with firm performance as measured by either Tobin's $Q$ or $R O A$. The economic magnitude is large. For example, on the intensive margin, consider column (1) in Table 6. The estimate implies that a one-standard-deviation increase in the Military Director Ratio (0.046), a variable that equals the ratio of military directors to board size, is associated with a 0.02 $(=0.046 * 0.412)$ decrease in a firm's Tobin's Q. This is equivalent to a $1 \%$ change when evaluated at the sample mean. On the extensive margin, consider column (4) in Table 6. The coefficient on Military Director Dummy, an indicator that equals one if a firm has at least one military director on its board, implies that firms with military directors are associated with a 0.005 drop in ROA compared to firms that are otherwise similar but have no military directors. The magnitude of the decrease is economically substantial since it amounts to $56 \%$ of the sample mean.

\section{[Insert Table 6 here]}

These empirical regularities suggest that the negative impacts of military directors on firm performance outweigh the positive ones in our sample. As emphasized by Griliches and Mason (1972), experience in the armed forces is a poor substitute for the lost experience in the labour market. Angrist $(1990,1998)$ and Angrist and Krueger (1994) further substantiate this argument by showing that veterans have lower earnings than their otherwise similar non-veteran counterparts.

Military directors who lack business experience, compared to their peers, can in turn produce poorer firm performance through the advisory mechanism. Indeed, a large literature documents that the business experience and knowledge of board directors play a critical role in firm growth (Francis, Hasan and Wu 2015, Güner, Malmendier and Tate 2008). Giannetti, Liao and $\mathrm{Yu}$ (2015), for instance, show that directors with experience of better management practices and corporate governance produce a substantial increase in firm performance. While our empirical 
results do not rule out the positive effects of military directors on firm performance, the negative impacts, which are consistent with the literature discussed above, seem to dominate in our sample.

\subsection{Addressing potential reverse causality}

It is important to note that our results may be subject to reverse causality. That is, firms with poorer performance may be more likely to appoint military directors in order to improve performance. Indeed, an extensive literature documents that directors with military experience serve as better monitors of firms' management teams and therefore enhance firm performance (e.g., Benmelech and Frydman 2015).

To address this concern, we firstly re-run our baseline analyses using an LFD model, in which we regress the changes in the measures of firm performance in year $t$ on the changes in the military director variables in year t-1. Like in model (2) in section 3.2, we include Market Capitalization, Leverage, PPE, Sales Growth, Board Size, Board Independence, Gender, Average Time on Board, and CEO Duality as our control variables. However, instead of the levels of these confounders, we use the changes in them in the year $t-1$.

Results from the LFD model are presented in Table 7. We find that our results on Tobin's Q become stronger both quantitatively and qualitatively. The results on ROA, however, become imprecisely estimated. One possible reason is that, due to a lack of business experience, military directors may put more emphasis on a firm's short-term profit at the expense of its long-term growth potential. Therefore, we observe little difference in ROA between firms with more versus fewer military directors, but a large difference in Tobin's Q, a measure of a firm's growth potential. Another possible explanation is the reduced sample size. Using the LFD model, our sample size decreases by about $40 \%$, which results in a larger standard error. Note that it is difficult to disentangle which explanation drives our results, or indeed whether it is both. Thus, we seek further evidence from a two-step dynamic GMM model. 
[Insert Table 7 here]

We re-run our analyses using a two-step dynamic panel system GMM model, which potentially allows us to circumvent both omitted variables and reverse causality issues (Blundell and Bond 1998, Judson and Owen 1999). In particular, we treat all dependent variables as endogenous, and instrument them using their lagged values in years $t-3$ and $t-4$, under the assumption that these lagged values influence the outcomes variables in year $t$ only through their values in year $t-1$ (Bun and Windmeijer 2010).

[Insert Table 8 here]

The estimates from the GMM model confirm our main results. We find that military directors significantly reduce firm performance as measured by either Tobin's Q or ROA. The economic magnitudes are qualitatively similar to those in our baseline results. For example, consider column (1) in Table 8. The coefficient on Military Director Ratio suggests that a onestandard-deviation increase in the ratio of military directors to board size (0.046) is associated with a decrease in a firm's Tobin's Q of $0.033(=0.710 * 0.046)$, which is a $1.7 \%$ decrease evaluated at the sample mean. The effects on ROA are also economically substantial. Take the coefficient in column (4) of Table 8. This estimate implies that, if a firm starts to hire military directors, then its ROA will suffer from a loss of 0.013 points, which is about 1.4 times the sample mean $(0.009)$.

In sum, the evidence from our OLS, LFD and GMM models taken together suggests that military directors are negatively associated with firm performance, measured by either the firm's Tobin's Q or its ROA. While the evidence on Tobin's Q is consistently robust across different model specifications that control for reverse causality and omitted variable issues, the results on firm ROA are sometimes imprecisely estimated. We present two possible reasons above and find support for the reduction in sample size explanation from the GMM estimations. Nonetheless, we suggest readers apply caution when interpreting our results. 


\subsection{Results from propensity score matching}

We also employ PSM to further test the relationship between military directors and firm performance, under the concern that the covariates included in the model may influence our results in a non-linear way. PSM allows us to estimate the treatment effects without assuming linear relationships between the covariates and the outcome variables.

In particular, a firm with military directors is matched to a firm without them, based on the propensity score from the fitted value of the following probit regression model:

$$
\text { Military }_{i j, c . t}=\alpha+\beta+\Phi Z_{i, j, c, t}^{\prime}+\Psi M_{i, j, c, t}^{\prime}+\gamma_{j}+\delta_{c}+\Upsilon_{t}+\varepsilon_{i, j, c, t}
$$

where the dependent variable Military $_{i j, c . t}$ is an indicator that equals one if a firm has at least one military director sitting on its board and zero otherwise. $Z_{i, j, c, t}^{\prime}$ is the same vector of firmlevel control variables as used in model (2), including Market Capitalization, Leverage, PPE, Sales Growth, Board Size, Board Independence, Gender, Average Time on Board, and CEO Duality. Industry, country and year fixed effects are also included. A new sample of firms with military directors and the matched firms without military directors is constructed based on the one-to-one nearestneighbour matching method. In sum, this new sample consists of 27,176 firm-year observations for Tobin's Q and 26,610 for ROA.

In Panel A of Table 9, we present our results from the probit model. The estimates suggest that firms of a bigger size and with a larger amount of debt are more likely to have a military director, as are firms with a larger board size, a higher level of board independence and more male directors ${ }^{4}$. Panel B of Table 9 shows the estimated treatment effects in our matched sample. We find that firms with military directors in general have worse performance as measured by either Tobin's Q or ROA. Also, the estimate effects are quantitatively similar to our baseline results.

\footnotetext{
${ }^{4}$ Although we tabulate the PSM results in Panel A of Table 9 using firm observable characteristics in year $t$, our estimation remains consistent when using firm characteristics in year $t-1$. We thank one of the referees for this valuable point.
} 
[Insert Table 9 here]

\subsection{Linking wars to firm performance}

Although we have linked war to an increase in the supply of military directors, and military directors to firm performance, we have not yet provided evidence on the direct impact of war on firm performance ${ }^{5}$. In this sub-section, we attempt to establish this relationship.

To do so, we first use the total number of wars that a country has experienced to predict the military director ratio and the probability of having a military director on a firm's board, respectively, conditional on a wide range of country- and firm-level characteristics. We then use these predicted measures as our main explanatory variables in model (2). As such, we attempt to isolate the variation in the military director measures that is determined by the total number of wars experienced by a country, and then link this source of variation to firm performance measures. Doing so allows us to test, at least partly, the direct impact of war on firm performance. This approach is widely used in the literature (e.g., Liang and Renneboog 2017[not in reference list]) and is similar to an instrumental variable (IV) approach except that the war variable is not treated as the instrument, as it is possible that war may operate on firm performance through channels other than the board directors.

In particular, to construct the predicted measures of military directors, we run the following specification:

$$
\text { Military Directors }_{i, j, c, t}=\alpha+\beta \text { War }_{c . t}+\Phi Z_{i, j, c, t}^{\prime}+\Gamma X_{c, t}^{\prime}+\gamma_{j}+\Upsilon_{t}+\varepsilon_{i, j, c, t}
$$

where the dependent variable Military Directors $_{i, j, c, t}$ is either Military Director Ratio, a measure calculated as the number of military directors on the board over the board size, or Military Director Dummy, an indicator that equals one if a firm has at least one military director sitting on its board

\footnotetext{
${ }^{5}$ We thank one of the referees for this valuable comment.
} 
and zero otherwise. $W a r_{c . t}$ is measured as the accumulated number of wars experienced by country cat year $t . Z^{\prime}{ }_{i, j, c, t}$ is a vector of firm-level control variables, including Market Capitalization, Leverage, PPE, Sales Growth, Board Size, Board Independence, Gender, Average Time on Board, and CEO Duality. $X_{c, t}^{\prime}$ is a vector of country-level control variables that include Army Size, Log(GDP per capita) and $\log \left(\right.$ Population). $\gamma_{j}$ and $Y_{t}$ are industry and year fixed effects. We cluster our standard errors at the country level.

We then use the predicted measures of military directors in model (2), and re-run our tests. As shown in Table 10, the coefficients are qualitatively similar to our previous estimates. Although it is difficult to interpret the coefficients when using predicted measures of military directors, this test does suggest that wars have a direct impact on firm performance through military directors.

$$
\text { [Insert Table } 10 \text { here] }
$$

\section{Robustness checks}

In this section, we perform two sets of robustness checks on our baseline results. First, we include various board director characteristics that are found to be important for firm performance in the literature. Then, we redo our main analyses on the relationship between military directors and firm performance, while controlling for military directors' frontline experience in the armed forces.

\subsection{Controlling for other board director characteristics}

An extensive literature documents the relationships between various board director characteristics and firm performance. For example, Adams and Ferreira (2009) show that female directors exert more effort in monitoring executives, and Gul, Srinidhi and $\mathrm{Ng}$ (2011) document that firms with more female directors have increased firm transparency. These results suggest that the gender composition of the corporate board has economic implications for firm performance. We therefore include a variable that measures the board's gender composition in our model. Güner, Malmendier and Tate (2008) show that board directors with commercial bank experience result in 
an increase in firm access to external financing, and directors with investment bank experience are associated with a larger amount of debt issuance. Therefore, it is important to also include an indicator of directors' financial experience. Several studies also find that directors with foreign experience can add value to firm performance. For example, Giannetti, Liao and Yu (2015) show that such directors can increase a firm's governance quality and thus promote firm growth. Masulis, Wang and Xie (2012) document that firms with foreign independent directors make better crossborder acquisitions when the targets are from their home countries. We thus include an indicator of board directors' foreign experience. Lastly, we include an indicator of board directors' legal experience in our models, since several influential studies suggest that legal experience can add value to firms, particularly via cross-border acquisitions (e.g., Masulis, Wang and Xie, 2012).

\section{[Insert Table 11 here]}

The results are presented in Table 11 . We find that our estimates remain qualitatively unchanged, even after controlling for Gender, Foreign Background, Financial Expertise and Legal Experience. For example, consider the estimate in column (1), Table 11. The coefficient on Military Director Ratio implies that a one-standard-deviation increase in the ratio of military directors to board size (0.046) is associated with a decrease in Tobin's Q of $0.017(=0.046 * 0.375)$, approximately a $1 \%$ decrease compared to the sample mean.

\subsection{Controlling for frontline experience}

Next, we re-run our baseline regressions while controlling for military directors' frontline experience in the armed forces. While all veterans receive similar basic training in the armed forces, they may have different experiences based on their roles in the army. Such heterogeneity in military experience may result in different implications for firm performance. BoardEx provides us with the roles the directors held when in the military, which allows us to distinguish frontline from other experiences. Specifically, we construct the variable Frontline as the proportion of military 
directors that possess frontline experience, defined as holding a frontline role when in the armed forces ${ }^{6}$.

[Insert Table 12 here]

We then include this variable in our main regression models specified in model (2). We present our results in Table 12. We find that our main results are unchanged even after controlling for frontline experience. That is, our measures of military directors are significantly, negatively associated with firm performance. The coefficients on the frontline measure are also insignificant, which suggests that, after taking military experience in general into account, frontline experience becomes unimportant.

\section{Military directors and firm leverage}

In this section, we present suggestive evidence on the relationship between military directors and firm leverage. While the results from previous sections taken together suggest a negative relationship between military directors and performance, and such evidence is consistent with existing theory in the literature (Angrist 1990, 1998, Angrist and Krueger 1994, Francis, Hasan and Wu 2015, Güner, Malmendier and Tate 2008), it is important to examine whether any firm policies reflect such a negative relationship. In particular, we ask whether firms with military directors have higher leverage, which could potentially increase the insolvency risk over the long run. Such evidence can help us understand the potential underlying mechanism linking military directors to negative firm performance.

We first run an OLS model that is similar to the model (2) specification, but where we replace the firm performance measures with a measure of firm leverage. We control for a wide

\footnotetext{
${ }^{6}$ The relevant roles are Adjutant General, Admiral, Air Marshall, Air Vice Marshall, Brigadier General, Captain, Chief of Air Staff, Chief of Defence Staff, Chief of General Staff, Chief of Naval Staff, Chief of Operations, Commandant, Commander, Commander-in-Chief, Commanding General, Commanding Officer, Commentator, Deputy Commander, Deputy Commander-in-Chief, Field Marshall, First Lieutenant, First Sea Lord/Chief of Naval Staff, General, Lieutenant, Lieutenant Colonel, Lieutenant Commander, Lieutenant General, Major, Major General, Military Assistant, Military Service, Naval Aviator, Second Lieutenant, Veterinarian, Vice Admiral, Vice Chief of Defence Staff, and Vice Commander.
} 
range of firm-level variables found to be important in the literature, namely Market Capitalization, Leverage, PPE, Sales Growth, Board Size, Board Independence, Gender, Average Time on Board, and CEO Duality. For detailed variable definitions, see Appendix 1. We also include industry, country, and year fixed effects in all regressions and cluster our standard errors at the country level.

\section{[Insert Table 13 here]}

Table 13 presents our results. We find that military directors are significantly, positively associated with firm leverage. The economic magnitude is large. Consider column (1) in Table 13, for example. The estimates imply that a one-standard-deviation increase in Military Director Ratio (0.046) is associated with an increase in firm leverage of $0.003\left(=0.046^{*} 0.058\right)$, a $0.6 \%$ increase evaluated at the sample mean. To address the potential reverse causality issue, we use an LFD model in which we regress the change in leverage for a firm in year $t$ on the changes in all independent variables in year $t-1$. We find that our results are qualitatively the same, as shown in Table 14.

\section{[Insert Table 14 here]}

In Table 15, we perform a simple test to alleviate the possible reverse causality concern. That is, firms with higher leverage may tend to employ more military directors. We regress the change in military directors in a firm on the change in leverage, while controlling for other firm characteristics. The results show that the coefficient on the change in leverage is not statistically meaningful, and therefore do not support the reverse causality claim.

$$
\text { [Insert Table } 15 \text { here] }
$$

\section{Conclusion and future research}

Understanding the link between war and its consequences is important, since nearly half of all countries in the world have experienced some form of war in the past few decades (Gleditsch et al. 2002, Harbom and Wallensteen 2007, Blattman and Miguel 2010). In this study, we shed light 
on this important topic by, firstly, documenting the negative relationships between wars and economic, financial, and legal development. We then discuss and present evidence on a new channel through which wars impact economic outcomes - military directors. While most of the previous studies on wars emphasize the damages of conflicts at the macro level (Collier et al. 2003, Barro 1991, Alesina et al. 1996, Alesina and Perotti 1996), we provide new evidence on how wars influence economic performance through a micro lens. We find that military directors damage firm performance, as measured by Tobin's Q and ROA. We also provide some evidence that military directors are associated with higher firm leverage, suggesting a potential channel through which military directors might influence firm performance.

This paper contributes to several strands of literature. First, it relates to studies that focus on the economic legacies of war (Cerra and Saxena 2008, Abadie and Gardeazabal 2003, Justino and Verwimp 2006). Unlike previous studies, we show that war hinders economic performance through the influence of military directors in war-affected areas. This implies that the influence of wars on the economy goes beyond the direct effects on physical and human capital. Second, we contribute to the literature on negative impacts of war on human capital (Alderman, Hoddinott and Kinsey 2006, Bundervoet, Verwimp and Akresh 2009, Shemyakina 2006). Our study sheds light on this literature by documenting that, for those who have found their way into skilled employment, war experiences can still exert adverse impacts on their performance. Lastly, our study speaks to the literature on post-war economic recovery (Davis and Weinstein 2002, Brakman, Garretsen and Schramm 2004, Miguel and Roland 2006). Our paper shows that war can have lasting impacts through human capital. Even wars that happened nearly 200 years ago can still have a negative influence on the affected regions.

We finally discuss several limitations of this study and provide some suggestions for future research. Firstly, there may be other firm policies that are not examined in this study but are affected by the presence of military directors on boards. To provide convincing evidence on the mechanisms that 
link military directors to firm performance, it will be necessary to collect more consistent information on firm policies in a global sample. In addition, if data on detailed board voting decisions existed for a global sample over a period of time, one could even disentangle the advisory and monitoring channels through which military directors might exert impacts on firm performance. Another potential fruitful area of research is policy interventions regarding veterans serving on corporate boards. It would be interesting to see how government policies that limited veterans' corporate board directorships might affect firm performance. However, such policies would be difficult to design and implement, since there may be heterogeneity in the relationship between military directors and firm growth. Such heterogeneity is itself another research area that warrants further study. Lastly, conditional on the results of the current study, an important research topic would be to further investigate the boundary conditions that might affect the direction of the relationship between military directors and firm performance. One such potential candidate boundary condition is the cost of obtaining inside information. As implied by Adams and Ferreira (2007), Harris and Raviv (2006), and Duchin, Matsusaka and Ozbas (2010), the positive effect on firm performance of heightened monitoring is more pronounced when the cost of obtaining relevant firm information is low. Since there is a lot of heterogeneity across firms in terms of their information environment, military directors may have a net positive impact on transparent firms.

\section{References:}

Abadie, Alberto, and Javier Gardeazabal. 2003. "The Economic Costs of Conflict: A Case Study of the Basque Country." American Economic Review, 93(1): 113-32.

Adams, Renee B., and Daniel Ferreira. 2007. "A theory of friendly boards." The Journal of Finance, 62(1): 217-50.

Adams, Renée B., and Daniel Ferreira. 2009. "Women in the boardroom and their impact on governance and performance." Journal of Financial Economics, 94(2): 291-309.

Agrawal, Anup, and Sahiba Chadha. 2005. "Corporate governance and accounting scandals." The Journal of Law and Economics, 48(2): 371-406. 
Ahern, Kenneth R., and Amy K. Dittmar. 2012. "The changing of the boards: The impact on firm valuation of mandated female board representation." The Quarterly Journal of Economics, 127(1): 137-97.

Alderman, Harold, John Hoddinott, and Bill Kinsey. 2006. "Long Term Consequences of Early Childhood Malnutrition." Oxford Economic Papers, 58(3): 450-74.

Alesina, Alberto, and Roberto Perotti. 1996. "Income Distribution, Political Instability, and Investment." European Economic Review, 40(6): 1203-28.

Alesina, Alberto, Sule Özler, Nouriel Roubini, and Phillip Swagel. 1996. "Political Instability and Economic Growth." Journal of Economic Growth, 1(2): 189-211.

An, Jiafu., Tinghua Duan, Wenxuan Hou and Xinyu Xu. 2019a. Initial Coin Offerings and Entrepreneurial Finance: The Role of Founders' Characteristics. The Journal of Alternative Investments, 21(4): 26-40.

An, Jiafu, Tinghua Duan, Wenxuan Hou and Xianda Liu. 2019b. "Legal Origins and Firm Environmental Performance: The Role of Lawyers in Boardrooms”. Working paper.

Angrist, Joshua D. 1990. "Lifetime Earnings and the Vietnam Era Draft Lottery: Evidence from Social Security Administrative Records." American Economic Review, 80(3): 313-36.

Angrist, Joshua D. 1998. "Estimating the Labor Market Impact of Voluntary Military Service Using Social Security Data on Military Applicants.” Econometrica, 66(2): 249-88.

Angrist, Joshua D., and Alan B. Krueger. 1994. "Why Do World War II Veterans Earn More than Nonveterans?" Journal of Labor Economics, 12(1): 74-97.

Barro, Robert J. 1991. "Economic Growth in a Cross Section of Countries." Quarterly Journal of Economics, 106(2): 407-43.

Bateson, Regina. 2012. "Crime Victimization and Political Participation.” American Political Science Review, 106(3): 570-87.

Bauer, Michal, Alessandra Cassar, Julie Chytilová, and Joseph Henrich. 2014. "War's Enduring Effects on the Development of Egalitarian Motivations and In-Group Biases." Psychological Science, 25(1): 47-57.

Bauer, Michal, Christopher Blattman, Julie Chytilová, Joseph Henrich, Edward Miguel and Tamar Mitts. 2016. “Can war foster cooperation?” Journal of Economic Perspectives, 30(3): 24974. 
Bebchuk, Lucian A., and Jesse M. Fried. 2005. "Pay without performance: Overview of the issues." Journal of Applied Corporate Finance, 17(4): 8-23.

Bellows, John, and Edward Miguel. 2006. "War and Institutions: New Evidence from Sierra Leone." American Economic Review, 96(2): 394-99.

Benmelech, Efraim, and Carola Frydman. 2015. "Military CEOs." Journal of Financial Economics, 117(1): 43-59.

Berger, Philip G., Eli Ofek, and David L. Yermack. 1997. "Managerial entrenchment and capital structure decisions." The Journal of Finance, 52(4): 1411-38.

Bertrand, Marianne, and Sendhil Mullainathan. 2003. "Enjoying the quiet life? Corporate governance and managerial preferences.” Journal of Political Economy, 111(5): 1043-75.

Blattman, Christopher. 2009. "From Violence to Voting: War and Political Participation in Uganda.” American Political Science Review, 103(2): 231-47.

Blattman, Christopher, and Edward Miguel. 2010. "Civil war." Journal of Economic Literature, 48(1): 3-57.

Blundell, Richard, and Stephen Bond. 1998. "Initial conditions and moment restrictions in dynamic panel data models.” Journal of Econometrics, 87(1): 115-43.

Bowles, Samuel. 2008. "Being Human: Conflict: Altruism’s Midwife.” Nature, November 20, 456(7220): 326-7.

Boyd, Brian K. 1994. "Board control and CEO compensation." Strategic Management Journal, 15(5): 335-44.

Brakman, Steven, Harry Garretsen, and Marc Schramm. 2004. "The strategic bombing of German cities during World War II and its impact on city growth.”Journal of Economic Geography, 4(2): 201-18.

Bun, Maurice J. G., and Frank Windmeijer. 2010. "The weak instrument problem of the system GMM estimator in dynamic panel data models.” The Econometrics Journal, 13(1): 95-126.

Burrough, B., and J. Helyar. 1990. Barbarians at the Gate. New York: Harper \& Row.

Bundervoet, Tom, Philip Verwimp, and Richard Akresh. 2009. "Health and civil war in rural Burundi.” Journal of Human Resources 44(2): 536-563. 
Cerra, Valerie, and Sweta Chaman Saxena. 2008. "Growth Dynamics: The Myth of Economic Recovery." American Economic Review, 98(1): 439-57.

Chhaochharia, V., and Y. Grinstein. 2007. "Corporate governance and firm value: The impact of the 2002 governance rules." The Journal of Finance, 62(4): 1789-825.

Collier, P., and M. Duponchel. 2012. "The economic legacy of civil war: firm-level evidence from Sierra Leone.” Journal of Conflict Resolution, 57(1): 65-88.

Collier, Paul, V. L. Elliott, Hâvard Hegre, Anke Hoeffler, Marta Reynal-Querol, and Nicholas Sambanis. 2003. Breaking the Conflict Trap: Civil War and Development Policy. Washington, D.C.: World Bank; Oxford and New York: Oxford University Press.

Dahya, Jay, and John J. McConnell. 2007. "Board composition, corporate performance, and the Cadbury committee recommendation." Journal of Financial and Quantitative Analysis, 42(3): 535-64.

Davis, Donald R., and David E. Weinstein. 2002. "Bones, Bombs, and Break Points: The Geography of Economic Activity." American Economic Review, 92(5): 1269-89.

DeFond, Mark L., Rebecca N. Hann, and Xuesong Hu. 2005. "Does the market value financial expertise on audit committees of boards of directors?" Journal of Accounting Research, 43(2): 153-93.

Deininger, Klaus. 2003a. "Does cost of schooling affect enrollment by the poor? Universal primary education in Uganda." Economics of Education Review, 22(3): 291-305.

Deininger, Klaus. 2003b. "Land policies for growth and poverty reduction." World Bank Publications.

Djankov, Simeon, Caralee McLiesh, and Andrei Shleifer. 2007. "Private credit in 129 countries." Journal of Financial Economics, 84(2): 299-329.

Djankov, Simeon, Oliver Hart, Caralee McLiesh, and Andrei Shleifer. 2008. "Debt enforcement around the world." Journal of Political Economy, 116(6): 1105-49.

Duchin, Ran, John G. Matsusaka, and Oguzhan Ozbas. 2010. "When are outside directors effective?" Journal of Financial Economics, 96(2): 195-214.

Ehlers, Anke, and David M. Clark. 2000. "A Cognitive Model of Posttraumatic Stress Disorder." Behaviour Research and Therapy, 38(4): 319-45. 
Fama, Eugene F., and Michael C. Jensen. 1983. "Separation of ownership and control." The Journal of Law and Economics, 26(2): 301-25.

Fortna, Virginia Page. 2004. Peace Time: Cease-Fire Agreements and the Durability of Peace. Princeton and Oxford: Princeton University Press.

Francis, Bill, Iftekhar Hasan, and Qiang Wu. 2015. "Professors in the boardroom and their impact on corporate governance and firm performance.” Financial Management, 44(3): 547-81.

Franke, V. C. 2001. "Generation X and the military: A comparison of attitudes and values between West Point cadets and college students." Journal of Political and Military Sociology, 29(1): 92.

Galovski, Tara, and Judith A. Lyons. 2004. "Psychological Sequelae of Combat Violence: A Review of the Impact of PTSD on the Veteran's Family and Possible Interventions." Aggression and Violent Behavior, 9(5): 477-501.

Ghobarah, Hazem Adam, Paul Huth, and Bruce Russett. 2003. "Civil Wars Kill and Maim PeopleLong after the Shooting Stops.” American Political Science Review, 97(2): 189-202.

Giannetti, Mariassunta, Guanmin Liao, and Xiaoyun Yu. 2015. "The brain gain of corporate boards: Evidence from China." The Journal of Finance, 70(4): 1629-82.

Gleditsch, Nils Petter, Peter Wallensteen, Mikael Eriksson, Margareta Sollenberg, and Hâvard Strand. 2002. "Armed Conflict 1946-2001: A New Dataset." Journal of Peace Research, 39(5): 615-37.

Griliches, Zvi, and William M. Mason. 1972. "Education, income, and ability." Journal of Political Economy, 80(3), Part 2: S74-S103.

Gul, Ferdinand A., Bin Srinidhi, and Anthony C. Ng. 2011. "Does board gender diversity improve the informativeness of stock prices?." Journal of Accounting and Economics 51(3): 314338.

Güner, A. Burak, Ulrike Malmendier, and Geoffrey Tate. 2008. "Financial expertise of directors." Journal of Financial Economics, 88(2): 323-54.

Harbom, Lotta, and Peter Wallensteen. 2007. "Armed Conflict, 1989-2006." Journal of Peace Research, 44(5): 623-34.

Harris, M., and A. Raviv. 2006. "A theory of board control and size." The Review of Financial Studies, 21(4): 1797-832. 
Helland, Eric, and Michael Sykuta. 2004. "Regulation and the evolution of corporate boards: Monitoring, advising, or window dressing?" The Journal of Law and Economics, 47(1): 167-93.

Hermalin, Benjamin E., and Michael S. Weisbach. 1991. "The effects of board composition and direct incentives on firm performance." Financial Management: 101-12.

Holmstrom, Bengt. 1979. "Moral hazard and observability." Bell Journal of Economics, 10(1): 7491.

Jensen, Michael C. 1986. "Agency costs of free cash flow, corporate finance, and takeovers." The American Economic Review, 76(2): 323-9.

Jensen, Michael C. 1988. “Takeovers: Their causes and consequences.” Journal of Economic Perspectives 2(1): 21-48.

Jensen, Michael C. 1993. "The modern industrial revolution, exit, and the failure of internal control systems." The Journal of Finance, 48(3): 831-80.

Jensen, Michael C., and William H. Meckling. 1976. "Theory of the firm: Managerial behavior, agency costs and ownership structure." Journal of Financial Economics, 3(4): 305-60.

Judson, Ruth A., and Ann L. Owen. 1999. "Estimating dynamic panel data models: a guide for macroeconomists." Economics Letters, 65(1): 9-15.

Justino, Patricia, and Philip Verwimp. 2006. "Poverty Dynamics, Violent Conflict and Convergence in Rwanda." Households in Conflict Network Working Paper 16.

Kesternich, Iris, and Monika Schnitzer. 2010. "Who is afraid of political risk? Multinational firms and their choice of capital structure." Journal of International Economics, 82(2): 208-18.

King, Robert G., and Ross Levine. 1993. "Finance and growth: Schumpeter might be right." The Quarterly Journal of Economics, 108(3): 717-37.

Knack, Stephen, and Philip Keefer. 1997. "Does social capital have an economic payoff? A crosscountry investigation." The Quarterly Journal of Economics, 112(4): 1251-88.

Levine, Ross. 2005. "Finance and growth: theory and evidence." Handbook of Economic Growth, 1: 865-934.

Liang, Hao, and Luc Renneboog. 2017. "On the foundations of corporate social responsibility." The Journal of Finance 72(2): 853-910. 
Lin, Chen, Micah S. Officer, and Hong Zou. 2011. "Directors' and officers' liability insurance and acquisition outcomes." Journal of Financial Economics, 102(3): 507-25.

Lin, Chen, Thomas Schmid, and Yuhai Xuan. 2018. "Employee representation and financial leverage." Journal of Financial Economics, 127(2): 303-24.

Lin, C., M. S. Officer, T. Schmid and H. Zou. 2019. "Is skin in the game a game changer? Evidence from mandatory changes of $\mathrm{D} \& \mathrm{O}$ insurance policies." Journal of Accounting and Economics, 101225

Lucas, Robert E., Jr. 1988. “On the Mechanics of Economic Development” Journal of Monetary Economics, 22(1): 3-42.

Mankiw, N. Gregory, David Romer, and David N. Weil. 1992. "A Contribution to the Empirics of Economic Growth.” Quarterly Journal of Economics, 107(2): 407-37.

Masulis, Ronald W., Cong Wang, and Fei Xie. 2012. "Globalizing the boardroom-The effects of foreign directors on corporate governance and firm performance." Journal of Accounting and Economics, 53(3): 527-54.

Miguel, Edward, and Gerald Roland. 2006. "The Long Run Impact of Bombing Vietnam." National Bureau of Economic Research Working Paper 11954.

Miguel, Edward, Sebastián M. Saiegh, and Shanker Satyanath. 2008. "National cultures and soccer violence.” No. w13968. National Bureau of Economic Research.

Mizruchi, Mark S. "Who controls whom? An examination of the relation between management and boards of directors in large American corporations." Academy of Management Review, 8(3): 426-35.

Popov, A. 2018. "Evidence on Finance and Economic Growth" in Beck, T., and R. Levine (eds.), Handbook of Finance and Development, Cheltenham, UK and Northampton, MA, USA: Edward Elgar Publishing, forthcoming.

La Porta, R., F. Lopez-de-Silanes, A. Shleifer and R. W. Vishny. 1998. "Law and finance.” Journal of Political Economy, 106(6): 1113-55.

Przeworski, Adam, Michael E. Alvarez, Jose Antonio Cheibub and Fernando Limongi. 2000. Democracy and Development: Political Institutions and Well-Being in the World, 19501990. Cambridge and New York: Cambridge University Press. 
Shemyakina, Olga. 2006. "The Effect of Armed Conflict on Accumulation of Schooling: Results from Tajikistan." Households in Conflict Network Working Paper 12.

Shivdasani, Anil, and David Yermack. 1999. "CEO involvement in the selection of new board members: An empirical analysis." The Journal of Finance, 54(5): 1829-53.

Shleifer, Andrei, and Robert W. Vishny. 1997. "A survey of corporate governance." The Journal of Finance, 52(2): 737-83.

Shleifer, Andrei, and Robert W. Vishny. 1989. "Management entrenchment: The case of managerspecific investments." Journal of Financial Economics 25(1): 123-139.

Tirole, J. 2006. The theory of corporate finance. Princeton University Press.

Toft, Monica Duffy. 2003. “Peace through Victory?” In Annual Meeting of the American Political Science Association, August, vol. 27, p. 31.

Voors, Maarten J., Eleonora E. M. Nillesen, Philip Verwimp, Erwin H. Bulte, Robert Lensink and Daan P. Van Soest. 2012. "Violent Conflict and Behavior: A Field Experiment in Burundi." American Economic Review, 102(2): 941-64.

Walsh, James P., and James K. Seward. 1990. "On the efficiency of internal and external corporate control mechanisms." Academy of Management Review, 15(3): 421-58.

Yermack, David. 2004. "Remuneration, retention, and reputation incentives for outside directors." The Journal of Finance, 59(5): 2281-308. 
Figure 1: Number of Wars by Country

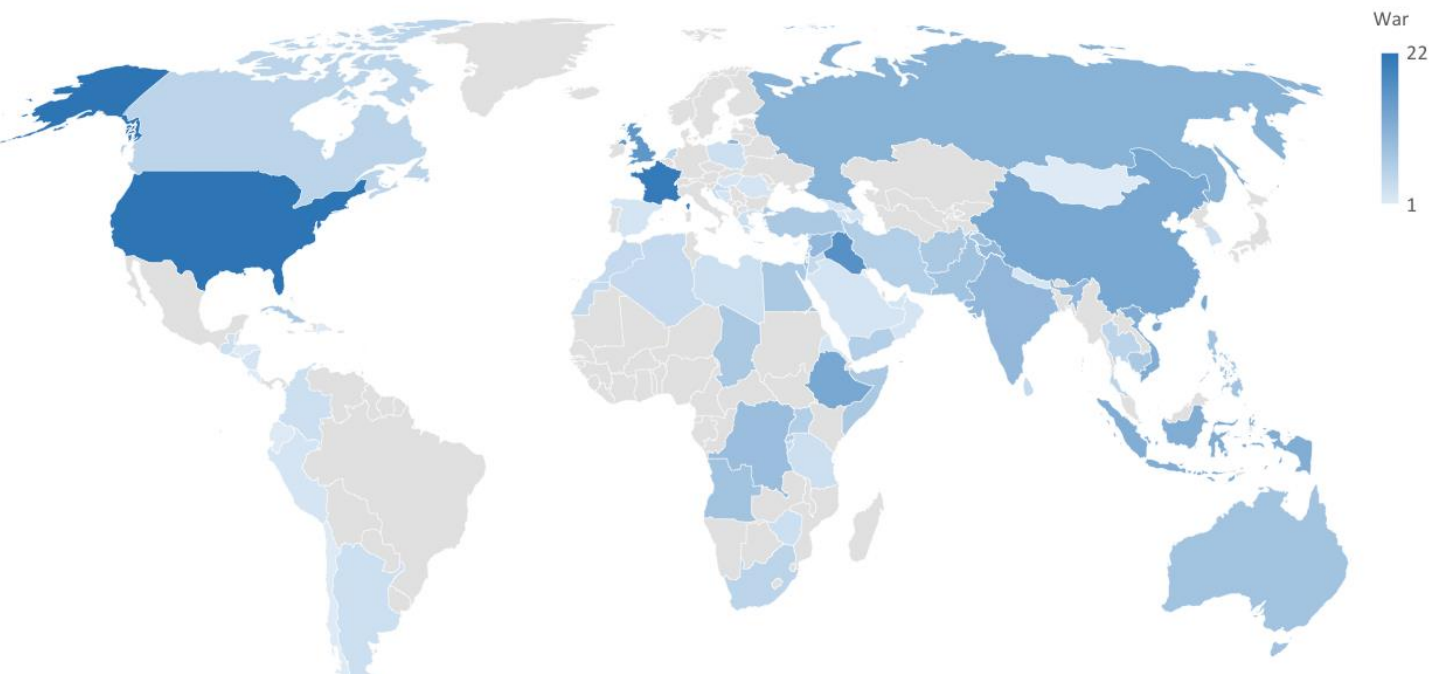


Figure 2: Number of Firms with Military Directors

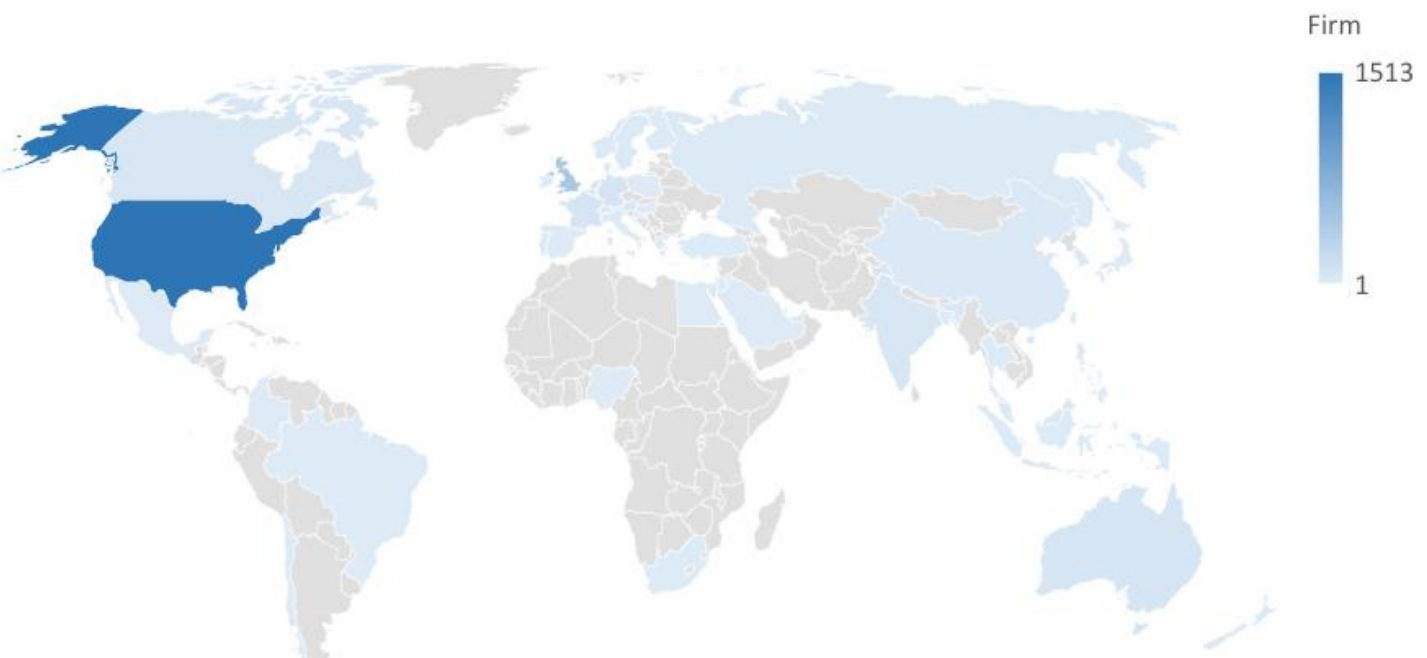


Table 1: Summary Statistics

\begin{tabular}{|c|c|c|c|c|c|}
\hline & Observation & Mean & $\mathrm{SD}$ & Min & Max \\
\hline \multicolumn{6}{|l|}{ Macro Level } \\
\hline War Involve (Number) & 5600 & 0.138 & 0.405 & 0.000 & 4.000 \\
\hline War Involve (Dummy) & 5600 & 0.120 & 0.325 & 0.000 & 1.000 \\
\hline No. of Soldier Deaths & 5600 & 33.297 & 314.349 & 0.000 & 4780.603 \\
\hline Private Credit to GDP & 2306 & 32.756 & 32.222 & 0.938 & 212.249 \\
\hline GDP Per Capita Growth \% & 2691 & 2.383 & 6.886 & -64.996 & 92.123 \\
\hline Rule of Law & 1506 & 3.579 & 1.452 & 0.000 & 6.000 \\
\hline Log(GDP per capita) & 2744 & 7.145 & 1.594 & 3.625 & 10.950 \\
\hline Log(Population) & 3453 & 16.394 & 1.456 & 11.524 & 21.004 \\
\hline Total War (Number) & 501 & 2.864 & 4.599 & 0.000 & 22.000 \\
\hline Total War (Year) & 501 & 2.966 & 6.190 & 0.000 & 35.000 \\
\hline Total Soldier Deaths & 501 & 1381.140 & 8944.416 & 0.000 & 66928.445 \\
\hline MiliFirm & 501 & 20.918 & 102.008 & 0.000 & 912.000 \\
\hline MilDirNum & 501 & 23.858 & 116.135 & 0.000 & 1028.000 \\
\hline \multicolumn{6}{|l|}{ Governance Level } \\
\hline Military Director Ratio & 128260 & 0.016 & 0.046 & 0.000 & 0.714 \\
\hline Military Director Dummy & 128260 & 0.140 & 0.347 & 0.000 & 1.000 \\
\hline Board Size & 128260 & 9.135 & 3.858 & 3.000 & 22.000 \\
\hline Board Independence & 128260 & 0.705 & 0.175 & 0.200 & 1.000 \\
\hline Gender & 128239 & 0.913 & 0.105 & 0.571 & 1.000 \\
\hline Average Time on Board & 128260 & 6.194 & 3.902 & 0.300 & 19.250 \\
\hline CEO Duality & 128260 & 0.312 & 0.463 & 0.000 & 1.000 \\
\hline Legal Expertise & 128260 & 0.100 & 0.300 & 0.000 & 1.000 \\
\hline Foreign Experience & 128260 & 0.286 & 0.452 & 0.000 & 1.000 \\
\hline Financial Expertise & 128260 & 0.243 & 0.429 & 0.000 & 1.000 \\
\hline \multicolumn{6}{|l|}{ Firm Level } \\
\hline Tobin’s Q & 91468 & 1.966 & 1.642 & 0.436 & 11.157 \\
\hline ROA & 91468 & 0.009 & 0.242 & -1.407 & 0.387 \\
\hline Market Capitalization & 91468 & 20.042 & 2.182 & 14.773 & 25.094 \\
\hline Leverage & 91468 & 0.504 & 0.261 & 0.008 & 1.452 \\
\hline PPE & 91468 & 0.524 & 0.418 & 0.003 & 1.932 \\
\hline Sales Growth & 91468 & 14.984 & 37.247 & -74.164 & 228.532 \\
\hline
\end{tabular}




\section{Table 2: War and GDP Per Capita Growth}

This table presents the results of regressing GDP per capita growth on proxies of wars. The dependent variable is GDP Per Capita Growth \% for each country in each year. Our key variables of interest are two indicators for war. War Involve (Number) is the total number of wars in a country in each year. War Involve (Dummy) is a dummy variable that equals one if there is a war in a country in a given year. No. of Soldier Deaths is the average number of deaths per war for a country in a given year. $\log$ (GDP per capita) is the natural logarithm of the GDP per capita. Log (Population) is the natural logarithm of the total population in each country. Robust standard errors are clustered at the country level and $t$ statistics are in brackets. $* * *, * *$ and $*$ denote significance levels of $1 \%, 5 \%$ and $10 \%$ respectively.

\begin{tabular}{|c|c|c|c|c|c|c|}
\hline & $(1)$ & $(2)$ & (3) & (4) & $(5)$ & (6) \\
\hline $\begin{array}{l}\text { War Involve } \\
\text { (Number) }\end{array}$ & $-1.3937^{* *}$ & $-1.5095^{* * *}$ & $-1.2108^{* *}$ & & & \\
\hline & $(-2.56)$ & $(-2.93)$ & $(-2.25)$ & & & \\
\hline War Involve (Dummy) & & & & $\begin{array}{c}-2.1721^{* * *} \\
(-3.43)\end{array}$ & $\begin{array}{c}-2.2812^{* * *} \\
(-3.91)\end{array}$ & $\begin{array}{c}-1.8596^{* * *} \\
(-2.98)\end{array}$ \\
\hline No. of Soldier Deaths & $\begin{array}{c}-0.0007 \\
(-1.40)\end{array}$ & $\begin{array}{c}0.0006 \\
(0.77)\end{array}$ & $\begin{array}{c}-0.0008^{*} \\
(-1.83)\end{array}$ & $\begin{array}{c}-0.0004 \\
(-0.83)\end{array}$ & $\begin{array}{c}0.0008 \\
(1.20)\end{array}$ & $\begin{array}{c}-0.0005 \\
(-1.32)\end{array}$ \\
\hline Log(GDP per capita) & & $\begin{array}{c}-0.1391 \\
(-1.05)\end{array}$ & $\begin{array}{c}-1.0089 \\
(-0.96)\end{array}$ & & $\begin{array}{c}-0.1596 \\
(-1.19)\end{array}$ & $\begin{array}{c}-1.0484 \\
(-1.00)\end{array}$ \\
\hline Log(Population) & & $\begin{array}{c}0.3257 \\
(1.64)\end{array}$ & $\begin{array}{c}-4.8786^{*} \\
(-1.73)\end{array}$ & & $\begin{array}{c}0.3308^{*} \\
(1.70)\end{array}$ & $\begin{array}{c}-4.9958^{*} \\
(-1.77)\end{array}$ \\
\hline Constant & $\begin{array}{c}2.6425^{* * *} \\
(10.79) \\
\end{array}$ & $\begin{array}{c}-1.7196 \\
(-0.49) \\
\end{array}$ & $\begin{array}{c}81.5555^{*} \\
(1.71) \\
\end{array}$ & $\begin{array}{c}2.7212^{* * *} \\
(11.13) \\
\end{array}$ & $\begin{array}{c}-1.5805 \\
(-0.45) \\
\end{array}$ & $\begin{array}{c}83.5289^{*} \\
(1.75) \\
\end{array}$ \\
\hline Country Fixed Effects & $\mathrm{NO}$ & $\mathrm{NO}$ & $\mathrm{YES}$ & $\mathrm{NO}$ & $\mathrm{NO}$ & YES \\
\hline Year Fixed Effects & $\mathrm{NO}$ & $\mathrm{NO}$ & YES & $\mathrm{NO}$ & $\mathrm{NO}$ & YES \\
\hline No. of Countries & 71 & 70 & 70 & 71 & 70 & 70 \\
\hline $\mathrm{R}^{2}$ & 0.010 & 0.013 & 0.159 & 0.014 & 0.017 & 0.162 \\
\hline Observations & 2691 & 2583 & 2583 & 2691 & 2583 & 2583 \\
\hline
\end{tabular}




\section{Table 3: War and Private Credit to GDP}

This table presents the results of regressing the ratio of private credit to GDP on proxies of wars. The dependent variable is Private Credit to GDP for each country in each year. Our key variables of interest are two indicators for war. War Involve (Number) is the total number of wars in a country in a given year. War Involve (Dummy) is a dummy variable that equals one if there is a war in a country in a given year. No. of Soldier Deaths is the average number of deaths per war for a country in a given year. $\log$ (GDP per capita) is the natural logarithm of the GDP per capita. Log (Population) is the natural logarithm of the total population in each country. Robust standard errors are clustered at the country level and $t$-statistics are in brackets. ${ }^{* * *}$, $* *$ and $*$ denote significance levels of $1 \%, 5 \%$ and $10 \%$ respectively.

\begin{tabular}{|c|c|c|c|c|c|c|}
\hline & $(1)$ & $(2)$ & $(3)$ & (4) & (5) & (6) \\
\hline \multirow{2}{*}{ War Involve (Number) } & -4.4398 & -2.5872 & $-3.5931^{* *}$ & & & \\
\hline & $(-1.04)$ & $(-1.11)$ & $(-2.32)$ & & & \\
\hline \multirow[t]{2}{*}{ War Involve (Dummy) } & & & & $-8.9473^{* * *}$ & $-5.2491^{* *}$ & $-4.8662^{* *}$ \\
\hline & & & & $(-2.66)$ & $(-2.09)$ & $(-2.44)$ \\
\hline \multirow{2}{*}{ No. of Soldier Deaths } & -0.0004 & -0.0003 & 0.0019 & 0.0016 & 0.0008 & 0.0025 \\
\hline & $(-0.07)$ & $(-0.11)$ & $(0.75)$ & $(0.32)$ & $(0.28)$ & $(0.94)$ \\
\hline \multirow[t]{2}{*}{ Log(GDP per capita) } & & $12.3582^{* * *}$ & $10.0858^{* * *}$ & & $12.2773^{* * *}$ & $9.9672^{* * *}$ \\
\hline & & $(7.42)$ & $(3.48)$ & & $(7.47)$ & $(3.44)$ \\
\hline \multirow{2}{*}{ Log(Population) } & & $6.6631^{* * *}$ & $-34.5367^{*}$ & & $6.7260^{* * *}$ & $-35.0825^{*}$ \\
\hline & & $(3.31)$ & $(-1.72)$ & & $(3.35)$ & $(-1.75)$ \\
\hline \multirow[t]{2}{*}{ Constant } & $33.5384^{* * *}$ & $-164.9606^{* * *}$ & 507.9705 & $34.0993^{* * *}$ & $-165.0988^{* * *}$ & 517.1748 \\
\hline & $(10.31)$ & $(-4.56)$ & $(1.57)$ & $(9.94)$ & $(-4.59)$ & $(1.60)$ \\
\hline Country Fixed Effects & $\mathrm{NO}$ & $\mathrm{NO}$ & YES & $\mathrm{NO}$ & $\mathrm{NO}$ & YES \\
\hline Year Fixed Effects & $\mathrm{NO}$ & $\mathrm{NO}$ & YES & $\mathrm{NO}$ & $\mathrm{NO}$ & YES \\
\hline No. of Countries & 69 & 69 & 69 & 69 & 69 & 69 \\
\hline $\mathrm{R}^{2}$ & 0.004 & 0.450 & 0.809 & 0.010 & 0.451 & 0.809 \\
\hline Observations & 2306 & 2272 & 2272 & 2306 & 2272 & 2272 \\
\hline
\end{tabular}




\section{Table 4: War and Rule of Law}

This table presents the results of regressing the rule of law index on proxies of wars. The dependent variable is Rule of Law from the ICRG database. Our key variables of interest are two indicators for war. War Involve (Number) is the total number of wars in a country in a given year. War Involve (Dummy) is a dummy variable that equals one if there is a war in a country in a given year. No. of Soldier Deatbs is the average number of deaths per war for a country in a given year. $\log ($ GDP per capita) is the natural logarithm of the GDP per capita. $\log$ (Population) is the natural logarithm of the total population in each country. Robust standard errors are clustered at the country level and $t$-statistics are in brackets. $* * *, * *$ and $*$ denote significance levels of $1 \%, 5 \%$ and $10 \%$ respectively.

\begin{tabular}{|c|c|c|c|c|c|c|}
\hline & $\begin{array}{c}\text { (1) } \\
\text { Rule of Law }\end{array}$ & $\begin{array}{c}\text { (2) } \\
\text { Rule of Law }\end{array}$ & $\begin{array}{c}\text { (3) } \\
\text { Rule of Law }\end{array}$ & $\begin{array}{c}\text { (4) } \\
\text { Rule of Law }\end{array}$ & $\begin{array}{c}\text { (5) } \\
\text { Rule of Law }\end{array}$ & $\begin{array}{c}\text { (6) } \\
\text { Rule of Law }\end{array}$ \\
\hline War Involve (Number) & $\begin{array}{c}-1.2719^{* * *} \\
(-4.54)\end{array}$ & $\begin{array}{c}-0.9847^{* * *} \\
(-3.58)\end{array}$ & $\begin{array}{c}-0.3925^{* *} \\
(-2.57)\end{array}$ & & & \\
\hline War Involve (Dummy) & & & & $\begin{array}{c}-1.3460^{* * *} \\
(-4.81)\end{array}$ & $\begin{array}{c}-1.0586^{* * *} \\
(-3.77)\end{array}$ & $\begin{array}{c}-0.4140^{* *} \\
(-2.54)\end{array}$ \\
\hline Number of Soldier Deaths & $\begin{array}{c}-0.0002 \\
(-0.79)\end{array}$ & $\begin{array}{c}-0.0003 \\
(-1.02)\end{array}$ & $\begin{array}{c}0.0001 \\
(0.58)\end{array}$ & $\begin{array}{c}-0.0001 \\
(-0.64)\end{array}$ & $\begin{array}{c}-0.0002 \\
(-0.89)\end{array}$ & $\begin{array}{c}0.0001 \\
(0.66)\end{array}$ \\
\hline Log(GDP per capita) & & $\begin{array}{c}0.5098^{* * *} \\
(6.60)\end{array}$ & $\begin{array}{c}0.3628^{*} \\
(1.86)\end{array}$ & & $\begin{array}{c}0.5093^{* * *} \\
(6.59)\end{array}$ & $\begin{array}{c}0.3644^{*} \\
(1.88)\end{array}$ \\
\hline Log(Population) & & $\begin{array}{c}0.2288^{* * *} \\
(4.66)\end{array}$ & $\begin{array}{c}1.5709^{*} \\
(1.99)\end{array}$ & & $\begin{array}{c}0.2292^{* * *} \\
(4.67)\end{array}$ & $\begin{array}{c}1.5803^{*} \\
(1.99)\end{array}$ \\
\hline Constant & $\begin{array}{c}3.7420^{* * *} \\
(25.93)\end{array}$ & $\begin{array}{c}-4.0927^{* * *} \\
(-3.89) \\
\end{array}$ & $\begin{array}{c}-26.2460^{*} \\
(-1.96) \\
\end{array}$ & $\begin{array}{c}3.7467^{* * *} \\
(25.93)\end{array}$ & $\begin{array}{c}-4.0908^{* * *} \\
(-3.90) \\
\end{array}$ & $\begin{array}{c}-26.4039^{*} \\
(-1.97) \\
\end{array}$ \\
\hline Country Fixed Effects & $\mathrm{NO}$ & $\mathrm{NO}$ & YES & $\mathrm{NO}$ & $\mathrm{NO}$ & YES \\
\hline Year Fixed Effects & $\mathrm{NO}$ & $\mathrm{NO}$ & YES & $\mathrm{NO}$ & $\mathrm{NO}$ & YES \\
\hline No. of Countries & 63 & 61 & 61 & 63 & 61 & 61 \\
\hline $\mathrm{R}^{2}$ & 0.094 & 0.361 & 0.801 & 0.097 & 0.365 & 0.801 \\
\hline Observations & 1506 & 1403 & 1403 & 1506 & 1403 & 1403 \\
\hline
\end{tabular}




\section{Table 5: War and Military Directors}

This table presents the results of regressing the supply of military directors on proxies of wars. The dependent variable is either MilDirNum, the total number of military directors in a country, or MiliFirm, the total number of firms that have at least one military director. Our key variables of interest are three indicators for war. Total War (Number) is the total number of wars in a country before a given year. Total War (Year) is the total number of years that a country is at war before a given year. Total Soldier Death is the total number of casualties for a country before a given year. Log (GDP per capita) is the natural logarithm of the GDP per capita. Log (Population) is the natural logarithm of the total population in each country. Log (Market Capitalization) is the natural logarithm of the total value of the stock market of a country in a given year. Robust standard errors are clustered at the country level and $t$-statistics are in brackets. $* * *, * *$ and $*$ denote significance levels of $1 \%, 5 \%$ and $10 \%$ respectively.

\begin{tabular}{|c|c|c|c|c|c|c|}
\hline & $\begin{array}{c}\text { (1) } \\
\text { MilDirNum }\end{array}$ & $\begin{array}{c}\text { (2) } \\
\text { MilDirNum }\end{array}$ & $\begin{array}{c}\text { (3) } \\
\text { MilDirNum }\end{array}$ & $\begin{array}{c}\text { (4) } \\
\text { MiliFirm }\end{array}$ & $\begin{array}{c}\text { (5) } \\
\text { MiliFirm }\end{array}$ & $\begin{array}{c}\text { (6) } \\
\text { MiliFirm }\end{array}$ \\
\hline Total War (Number) & $\begin{array}{l}36.085^{*} \\
(1.905)\end{array}$ & & & $\begin{array}{c}33.745^{*} \\
(1.895)\end{array}$ & & \\
\hline Total War (Year) & & $\begin{array}{c}27.082^{* *} \\
(2.373)\end{array}$ & & & $\begin{array}{c}24.273^{* *} \\
(2.369)\end{array}$ & \\
\hline Total Soldier Deaths & & & $\begin{array}{l}0.154^{* * *} \\
(150.836)\end{array}$ & & & $\begin{array}{l}0.139 * * * \\
(143.734)\end{array}$ \\
\hline Log(GDP per capita) & $\begin{array}{l}-41.042 \\
(-1.485)\end{array}$ & $\begin{array}{l}-54.866 \\
(-1.349)\end{array}$ & $\begin{array}{l}-41.931 \\
(-1.284)\end{array}$ & $\begin{array}{l}-36.224 \\
(-1.374)\end{array}$ & $\begin{array}{l}-49.867 \\
(-1.262)\end{array}$ & $\begin{array}{l}-38.200 \\
(-1.193)\end{array}$ \\
\hline Log(Population) & $\begin{array}{l}27.475 \\
(0.570)\end{array}$ & $\begin{array}{l}-40.914 \\
(-1.174)\end{array}$ & $\begin{array}{l}-19.535 \\
(-0.868)\end{array}$ & $\begin{array}{l}22.067 \\
(0.531)\end{array}$ & $\begin{array}{l}-40.342 \\
(-1.192)\end{array}$ & $\begin{array}{l}-21.224 \\
(-1.083)\end{array}$ \\
\hline Log(Market Capitalization) & $\begin{array}{c}0.818 \\
(0.531)\end{array}$ & $\begin{array}{c}-1.861 \\
(-1.070)\end{array}$ & $\begin{array}{c}-0.252 \\
(-0.278)\end{array}$ & $\begin{array}{c}0.568 \\
(0.397)\end{array}$ & $\begin{array}{c}-1.855 \\
(-1.126)\end{array}$ & $\begin{array}{c}-0.414 \\
(-0.475)\end{array}$ \\
\hline Constant & $\begin{array}{c}-296.145 \\
(-0.352)\end{array}$ & $\begin{array}{c}1120.847 \\
(1.384)\end{array}$ & $\begin{array}{c}677.766 \\
(1.278)\end{array}$ & $\begin{array}{c}-225.672 \\
(-0.314)\end{array}$ & $\begin{array}{c}1077.706 \\
(1.389)\end{array}$ & $\begin{array}{c}680.852 \\
(1.388)\end{array}$ \\
\hline Country Fixed Effect & Yes & Yes & Yes & Yes & Yes & Yes \\
\hline Year Fixed Effect & Yes & Yes & Yes & Yes & Yes & Yes \\
\hline No. of Countries & 74 & 74 & 74 & 74 & 74 & 74 \\
\hline $\mathrm{R}^{2}$ & 0.906 & 0.942 & 0.974 & 0.900 & 0.936 & 0.970 \\
\hline Observations & 433 & 433 & 433 & 433 & 433 & 433 \\
\hline
\end{tabular}




\section{Table 6 Military Directors and Firm Performance}

This table presents the results of regressing firm performance measures on military directors. The dependent variable is either Tobin's $Q$ in columns (1) and (2) or $R O A$ in columns (3) and (4). Our key variables of interest are two measures of military directors. Military Director Ratio is the ratio of military directors to the total number of directors on a board. Military Director Dummy is an indicator that equals one if a firm has a military director and zero otherwise. Market Capitalization is the natural logarithm of the value of the stock market. Leverage is the ratio of total liabilities to total assets. PPE is the ratio of the value of property, plant and equipment to total assets. Sales Growth is the three-year average growth rate of the net sales. Board Size is the total number of board directors in year $t$. Board Independence is the ratio of non-executive directors to the total number of directors in year t. Gender is the ratio of the number of male directors to the total number of directors. Average Time on Board is the average tenure of all the directors on the board. CEO Duality is a dummy variable that equals one if the CEO is also the chairman of the board. Robust standard errors are clustered at the country level and $t$-statistics are in brackets. $* * *, * *$ and $*$ denote significance levels of $1 \%, 5 \%$ and $10 \%$ respectively.

\begin{tabular}{|c|c|c|c|c|}
\hline \multirow[b]{3}{*}{ Military Director Ratio } & \multicolumn{2}{|c|}{ Tobin's Q } & \multicolumn{2}{|c|}{ ROA } \\
\hline & (1) & (2) & (3) & (4) \\
\hline & $\begin{array}{c}-0.4119^{* *} \\
(-2.15)\end{array}$ & & $\begin{array}{l}-0.0200 \\
(-1.29)\end{array}$ & \\
\hline Military Director Dummy & & $\begin{array}{c}-0.0617^{* * *} \\
(-2.84)\end{array}$ & & $\begin{array}{r}-0.0052^{* *} \\
(-2.57)\end{array}$ \\
\hline Market Capitalization & $\begin{array}{c}0.2342^{* * *} \\
(9.76)\end{array}$ & $\begin{array}{c}0.2343^{* * *} \\
(9.78)\end{array}$ & $\begin{array}{c}0.0494^{* * *} \\
(18.35)\end{array}$ & $\begin{array}{c}0.0494^{* * *} \\
(18.34)\end{array}$ \\
\hline Leverage & $\begin{array}{c}0.2397^{*} \\
(1.89)\end{array}$ & $\begin{array}{c}0.2402^{*} \\
(1.90)\end{array}$ & $\begin{array}{c}-0.1314^{* * *} \\
(-18.45)\end{array}$ & $\begin{array}{l}-0.1313^{* * *} \\
(-18.46)\end{array}$ \\
\hline PPE & $\begin{array}{c}-0.3783^{* * *} \\
(-5.57)\end{array}$ & $\begin{array}{c}-0.3786^{* * *} \\
(-5.58)\end{array}$ & $\begin{array}{c}0.0205^{* *} \\
(2.46)\end{array}$ & $\begin{array}{c}0.0204^{* *} \\
(2.45)\end{array}$ \\
\hline Sales Growth & $\begin{array}{c}0.0029^{* * *} \\
(3.04)\end{array}$ & $\begin{array}{c}0.0029^{* * *} \\
(3.04)\end{array}$ & $\begin{array}{l}0.0002^{* * *} \\
(3.48)\end{array}$ & $\begin{array}{c}0.0002^{* * *} \\
(3.48)\end{array}$ \\
\hline Board Size & $\begin{array}{c}-0.1189^{* * *} \\
(-6.65)\end{array}$ & $\begin{array}{c}-0.1181^{* * *} \\
(-6.69)\end{array}$ & $\begin{array}{c}-0.0043^{* * *} \\
(-5.70)\end{array}$ & $\begin{array}{r}-0.0042^{* * *} \\
(-5.63)\end{array}$ \\
\hline Board Independence & $\begin{array}{c}-0.7044^{* * *} \\
(-5.00)\end{array}$ & $\begin{array}{c}-0.7044^{* * *} \\
(-5.01)\end{array}$ & $\begin{array}{c}-0.0426^{* * *} \\
(-3.38)\end{array}$ & $\begin{array}{c}-0.0424^{* * *} \\
(-3.38)\end{array}$ \\
\hline Gender & $\begin{array}{c}0.1837^{*} \\
(1.86)\end{array}$ & $\begin{array}{c}0.1822^{*} \\
(1.84)\end{array}$ & $\begin{array}{c}-0.0564^{* * *} \\
(-4.57)\end{array}$ & $\begin{array}{r}-0.0565^{* * *} \\
(-4.58)\end{array}$ \\
\hline Average Time on Board & $\begin{array}{l}-0.0195^{* * *} \\
(-7.96)\end{array}$ & $\begin{array}{l}-0.0195^{* * *} \\
(-7.93)\end{array}$ & $\begin{array}{l}0.0088^{* * *} \\
(11.58)\end{array}$ & $\begin{array}{c}0.0088^{* * *} \\
(11.56)\end{array}$ \\
\hline CEO Duality & $\begin{array}{c}-0.0504 \\
(-0.83)\end{array}$ & $\begin{array}{c}-0.0502 \\
(-0.83)\end{array}$ & $\begin{array}{l}0.0073 \\
(1.03)\end{array}$ & $\begin{array}{l}0.0073 \\
(1.03)\end{array}$ \\
\hline Constant & $\begin{array}{c}0.8526^{* * *} \\
(3.41)\end{array}$ & $\begin{array}{c}0.8422^{* * * *} \\
(3.34)\end{array}$ & $\begin{array}{c}-0.8413^{* * *} \\
(-10.34)\end{array}$ & $\begin{array}{c}-0.8427^{* * *} \\
(-10.33)\end{array}$ \\
\hline $\begin{array}{l}\text { Industry, Country, and } \\
\text { Year Fixed Effects }\end{array}$ & YES & YES & YES & YES \\
\hline$R^{2}$ & 0.181 & 0.181 & 0.260 & 0.260 \\
\hline Observations & 93697 & 93697 & 91460 & 91460 \\
\hline
\end{tabular}




\section{Table 7: Military Directors and Firm Performance, Lagged Difference Model}

This table shows the results for military directors against firm performance, obtained from a lagged difference model. The dependent variables are the differenced values of Tobin's $Q$ in columns (1) and (2) and ROA in columns (3) and (4). Our key variable of interest is either $\Delta$ Military Director Ratio, the change in the ratio of military directors to board size in year $t-1$, or $\Delta$ Military Director Dummy, the change in the military dummy variable in year $t-1$. Control variables are the same as in Table 6, but, instead of the levels, we are using the changes in year $t-1$. For detailed variable definitions, see Appendix 1. Robust standard errors are clustered at the country level and $t$-statistics are in brackets. ${ }^{* * *},{ }^{* *}$ and $*$ denote significance levels of $1 \%, 5 \%$ and $10 \%$ respectively.

\begin{tabular}{|c|c|c|c|c|}
\hline \multirow[b]{3}{*}{$\Delta$ Military Director Ratio } & \multicolumn{2}{|c|}{$\Delta$ Tobin's $\mathrm{Q}$} & \multicolumn{2}{|c|}{$\triangle \mathrm{ROA}$} \\
\hline & (1) & (2) & (3) & (4) \\
\hline & $\begin{array}{c}-0.623 * * * \\
(-2.794)\end{array}$ & & $\begin{array}{c}-0.004 \\
(-0.166)\end{array}$ & \\
\hline$\Delta$ Military Director Dum & & $\begin{array}{c}-0.054 * * \\
(-2.132)\end{array}$ & & $\begin{array}{c}0.000 \\
(0.421)\end{array}$ \\
\hline$\Delta$ Market Capitalization & $\begin{array}{c}-0.201 * * * \\
(-11.854)\end{array}$ & $\begin{array}{c}-0.201 * * * \\
(-11.890)\end{array}$ & $\begin{array}{c}-0.023 * * * \\
(-8.694)\end{array}$ & $\begin{array}{c}-0.023 * * * \\
(-8.698)\end{array}$ \\
\hline$\Delta$ Leverage & $\begin{array}{c}-0.102 * * \\
(-2.112)\end{array}$ & $\begin{array}{c}-0.102^{* *} \\
(-2.088)\end{array}$ & $\begin{array}{c}0.035^{* *} \\
(2.131)\end{array}$ & $\begin{array}{c}0.035^{* *} \\
(2.133)\end{array}$ \\
\hline$\Delta \mathrm{PPE}$ & $\begin{array}{c}0.219 * * * \\
(6.792)\end{array}$ & $\begin{array}{c}0.219^{* * *} \\
(6.779)\end{array}$ & $\begin{array}{c}0.016 \\
(1.347)\end{array}$ & $\begin{array}{c}0.016 \\
(1.347)\end{array}$ \\
\hline$\Delta$ Sales Growth & $\begin{array}{l}-0.000 \\
(-0.961)\end{array}$ & $\begin{array}{l}-0.000 \\
(-0.956)\end{array}$ & $\begin{array}{c}-0.000 \\
(-0.954)\end{array}$ & $\begin{array}{c}-0.000 \\
(-0.954)\end{array}$ \\
\hline$\Delta$ Board Size & $\begin{array}{c}-0.009 * * * \\
(-2.906)\end{array}$ & $\begin{array}{c}-0.009 * * \\
(-2.628)\end{array}$ & $\begin{array}{c}-0.000 \\
(-0.223)\end{array}$ & $\begin{array}{c}-0.000 \\
(-0.239)\end{array}$ \\
\hline$\Delta$ Board Independence & $\begin{array}{c}0.007 \\
(0.159)\end{array}$ & $\begin{array}{c}0.003 \\
(0.068)\end{array}$ & $\begin{array}{c}-0.013 \\
(-0.859)\end{array}$ & $\begin{array}{c}-0.014 \\
(-0.861)\end{array}$ \\
\hline$\Delta$ Gender & $\begin{array}{c}0.116 \\
(1.560)\end{array}$ & $\begin{array}{c}0.115 \\
(1.539)\end{array}$ & $\begin{array}{c}0.018 \\
(1.417)\end{array}$ & $\begin{array}{c}0.018 \\
(1.396)\end{array}$ \\
\hline$\Delta$ Average Time on & $\begin{array}{c}-0.005^{* * *} \\
(-2.808)\end{array}$ & $\begin{array}{c}-0.005 * * * \\
(-2.800)\end{array}$ & $\begin{array}{c}-0.001 \\
(-1.419)\end{array}$ & $\begin{array}{c}-0.001 \\
(-1.435)\end{array}$ \\
\hline$\Delta$ CEO Duality & $\begin{array}{c}0.010 \\
(0.838)\end{array}$ & $\begin{array}{c}0.010 \\
(0.824)\end{array}$ & $\begin{array}{c}0.002 \\
(0.789)\end{array}$ & $\begin{array}{c}0.002 \\
(0.785)\end{array}$ \\
\hline Constant & $\begin{array}{c}-0.021 * * * \\
(-2.970)\end{array}$ & $\begin{array}{c}-0.021 * * * \\
(-2.950)\end{array}$ & $\begin{array}{c}-0.005^{* * *} \\
(-4.224)\end{array}$ & $\begin{array}{c}-0.005^{* * *} \\
(-4.205)\end{array}$ \\
\hline $\mathrm{R}^{2}$ & 0.017 & 0.017 & 0.008 & 0.008 \\
\hline Observations & 56884 & 56884 & 55282 & 55282 \\
\hline
\end{tabular}




\section{Table 8: Military Directors and Firm Performance, GMM Model}

This table presents the results of two-step dynamic GMM estimations of military directors on firm performance, allowing for two lags of the dependent variables. All independent variables are instrumented by their lagged values in years $t-3$ and $t-4$, assuming they influence the outcome variables only through their values at year t-1. The dependent variable is either Tobin's $Q$ in columns (1) and (2) or ROA in columns (3) and (4). Our key variable of interest is either Military Director Ratio, the ratio of military directors to board size, or Military Director Dummy, an indicator that equals one if a firm has at least one military director on its board and zero otherwise. Control variables include Market Capitalization, Leverage, PPE, Sales Growth, Board Size, Board Independence, Gender, Average Time on Board, and CEO Duality. For detailed variable definitions, see Appendix 1. AR (1) and AR (2) are tests for first-order and second-order serial correlation in the firstdifferenced residuals, under the null hypothesis of no serial correlation. T-statistics are based on robust standard errors and presented in brackets. $* * *, * *$ and $*$ denote significance levels of $1 \%$, $5 \%$ and $10 \%$ respectively.

\begin{tabular}{|c|c|c|c|c|}
\hline \multirow{3}{*}{ Military Director Ratio } & \multicolumn{2}{|c|}{ Tobin's Q } & \multicolumn{2}{|c|}{$\mathrm{ROA}$} \\
\hline & (1) & $(2)$ & (3) & (4) \\
\hline & $-0.710^{* *}$ & & -0.084 & \\
\hline Military Director Dummy & & $\begin{array}{c}-0.085^{* *} \\
(-2.391)\end{array}$ & & $\begin{array}{c}-0.013^{* *} \\
(-2.017)\end{array}$ \\
\hline Market Capitalization & $\begin{array}{c}-0.049 * * * \\
(-2.759)\end{array}$ & $\begin{array}{c}-0.048^{* * *} \\
(-2.745)\end{array}$ & $\begin{array}{c}0.013 * * \\
(2.219)\end{array}$ & $\begin{array}{c}0.013^{* *} \\
(2.234)\end{array}$ \\
\hline Leverage & $\begin{array}{c}0.328^{* * *} \\
(3.129)\end{array}$ & $\begin{array}{c}0.328 * * * \\
(3.139)\end{array}$ & $\begin{array}{c}0.004 \\
(0.202)\end{array}$ & $\begin{array}{c}0.004 \\
(0.200)\end{array}$ \\
\hline PPE & $\begin{array}{c}-0.030 \\
(-0.400)\end{array}$ & $\begin{array}{c}-0.029 \\
(-0.394)\end{array}$ & $\begin{array}{c}-0.010 \\
(-0.736)\end{array}$ & $\begin{array}{c}-0.010 \\
(-0.749)\end{array}$ \\
\hline Sales Growth & $\begin{array}{c}0.000 \\
(0.434)\end{array}$ & $\begin{array}{c}0.000 \\
(0.432)\end{array}$ & $\begin{array}{c}-0.000 \\
(-0.285)\end{array}$ & $\begin{array}{l}-0.000 \\
(-0.316)\end{array}$ \\
\hline Board Size & $\begin{array}{c}-0.014 * * \\
(-2.132)\end{array}$ & $\begin{array}{c}-0.013^{* *} \\
(-1.999)\end{array}$ & $\begin{array}{c}-0.004 * * \\
(-2.549)\end{array}$ & $\begin{array}{c}-0.004 * * \\
(-2.425)\end{array}$ \\
\hline Board Independence & $\begin{array}{c}0.151 \\
(0.947)\end{array}$ & $\begin{array}{c}0.157 \\
(0.982)\end{array}$ & $\begin{array}{c}0.010 \\
(0.348)\end{array}$ & $\begin{array}{c}0.011 \\
(0.390)\end{array}$ \\
\hline Gender & $\begin{array}{l}-0.072 \\
(-0.377)\end{array}$ & $\begin{array}{c}-0.075 \\
(-0.396)\end{array}$ & $\begin{array}{c}-0.005 \\
(-0.144)\end{array}$ & $\begin{array}{c}-0.005 \\
(-0.148)\end{array}$ \\
\hline Average Time on Board & $\begin{array}{c}-0.001 \\
(-0.189)\end{array}$ & $\begin{array}{c}-0.001 \\
(-0.275)\end{array}$ & $\begin{array}{c}-0.001 \\
(-1.263)\end{array}$ & $\begin{array}{c}-0.001 \\
(-1.284)\end{array}$ \\
\hline CEO Duality & $\begin{array}{c}0.002 \\
(0.066)\end{array}$ & $\begin{array}{c}0.000 \\
(0.008)\end{array}$ & $\begin{array}{c}0.003 \\
(0.396)\end{array}$ & $\begin{array}{c}0.003 \\
(0.393)\end{array}$ \\
\hline L.Tobin's Q & $\begin{array}{c}0.711 * * * \\
(9.285)\end{array}$ & $\begin{array}{c}0.708 * * * \\
(9.264)\end{array}$ & $\begin{array}{l}- \\
-\end{array}$ & $\begin{array}{l}- \\
-\end{array}$ \\
\hline L2.Tobin's Q & $\begin{array}{c}-0.013 \\
(-0.298)\end{array}$ & $\begin{array}{c}-0.011 \\
(-0.251)\end{array}$ & $\begin{array}{l}- \\
-\end{array}$ & $\begin{array}{l}- \\
-\end{array}$ \\
\hline L.ROA & $\begin{array}{c}-0.201 \\
- \\
-\end{array}$ & $\begin{array}{c}(-0.251) \\
- \\
-\end{array}$ & $\begin{array}{c}0.697 * * * \\
(9.447)\end{array}$ & $\begin{array}{c}0.695^{* * *} \\
(9.364)\end{array}$ \\
\hline L2.ROA & $\begin{array}{l}- \\
-\end{array}$ & $\begin{array}{l}- \\
-\end{array}$ & $\begin{array}{c}-0.059 * * \\
(-2.377)\end{array}$ & $\begin{array}{c}-0.059 * * \\
(-2.343)\end{array}$ \\
\hline Constant & $\begin{array}{c}1.313^{* * *} * \\
(2.666)\end{array}$ & $\begin{array}{c}1.303 * * * \\
(2.655)\end{array}$ & $\begin{array}{c}0.000 \\
(.)\end{array}$ & $\begin{array}{c}0.000 \\
(.)\end{array}$ \\
\hline AR(1) test ( $t$-value) & 0.000 & 0.000 & 0.000 & 0.000 \\
\hline $\operatorname{AR}(2)$ test ( $p$-value) & 0.261 & 0.278 & 0.000 & 0.000 \\
\hline Year Dummies & Yes & Yes & Yes & Yes \\
\hline Observations & 70365 & 70365 & 67762 & 67762 \\
\hline
\end{tabular}




\section{Table 9: Military Directors and Firm Performance by PSM}

This table presents the results of one-to-one propensity score matching of nearest neighbour, based on Market Capitalization, Leverage, PPE, Sales Growth, Board Size, Board Independence, Gender, Average Time on Board, and CEO Duality. The dependent variable in Panel A is Military Director Dummy, which is a dummy variable that equals one if the firm has at least one military director on its board. For detailed variable definitions, see Appendix 1 . Robust standard errors are clustered at the country level and $t$-statistics are in brackets. ${ }^{* * *}, * *$ and $*$ denote significance levels of $1 \%, 5 \%$ and $10 \%$ respectively.

\section{Panel A: Determinants of Boards with Military Directors}

Market Capitalization Military Director Dummy

Leverage

$0.0660^{* * *}$

(9.72)

$0.1599^{* * *}$

(3.72)

PPE

$(0.08)$

Sales Growth

Board Size

$0.1460^{* * *}$

(35.80)

Board Independence

Gender

Average Time on Board

CEO Duality

Constant

Chdustry Fixed Effects $(-23.22)$

Country Fixed Effects YES

YES

Year Fixed Effects

YES

Pseudo R ${ }^{2}$

0.1167

Observations

93292

\section{Panel B: Average Treatment Effects}

Observations

Mean of Treated Tobin's Q ROA 13588 13305

Observations 1.9475

0.0312

Mean of Matched Non-Treated

13588

13305

Difference-in-Mean

1.9996

0.0359

$t$-statistics

$-0.0521 * * *$

$-0.0047 *$

$-2.85$ $-1.85$ 


\section{Table 10: Military Directors and Performance, Controlling for Other Board Director Characteristics}

This table presents the estimated impacts of military directors on firm performance while controlling for other board director characteristics. The dependent variable is either Tobin's $Q$ or ROA. Our key variable of interest is either Military Director Ratio, which is the ratio of military directors to board size, or Military Director Dummy, which is an indicator that equals one if a firm has at least one military director and zero otherwise. Other board director characteristics include Legal Expertise, an indicator that equals one if the proportion of directors with a legal background is above the industry median value and zero otherwise, Foreign Background, an indicator that equals one if the proportion of directors with foreign experience is above the industry median value and zero otherwise, and Financial Expertise, an indicator that equals one if the proportion of directors with financial experience is above the industry median value and zero otherwise. For detailed variable definitions, see Appendix 1. Robust standard errors are clustered at the country level and $t$-statistics are in brackets. ${ }^{* *},{ }^{* *}$ and $*$ denote significance levels of $1 \%, 5 \%$ and $10 \%$ respectively.

\begin{tabular}{|c|c|c|c|c|}
\hline \multirow{3}{*}{ Military Director Ratio } & \multicolumn{2}{|c|}{ Tobin's Q } & \multicolumn{2}{|c|}{ ROA } \\
\hline & $(1)$ & (2) & (3) & (4) \\
\hline & $\begin{array}{l}-0.375^{*} \\
(-1.958)\end{array}$ & & $\begin{array}{c}-0.014 \\
(-0.910)\end{array}$ & \\
\hline Military Director Dummy & & $\begin{array}{c}-0.056 * * \\
(-2.580)\end{array}$ & & $\begin{array}{l}-0.004^{*} \\
(-2.028)\end{array}$ \\
\hline Market Capitalization & $\begin{array}{c}0.236 * * * \\
(9.437)\end{array}$ & $\begin{array}{c}0.236^{* * *} \\
(9.452)\end{array}$ & $\begin{array}{c}0.051 * * * \\
(19.634)\end{array}$ & $\begin{array}{c}0.051 * * * \\
(19.617)\end{array}$ \\
\hline Leverage & $\begin{array}{l}0.245^{*} \\
(1.939)\end{array}$ & $\begin{array}{l}0.245^{*} \\
(1.944)\end{array}$ & $\begin{array}{r}-0.130 * * * \\
(-18.332)\end{array}$ & $\begin{array}{r}-0.130 * * * \\
(-18.343)\end{array}$ \\
\hline PPE & $\begin{array}{c}-0.378^{* * *} \\
(-5.477)\end{array}$ & $\begin{array}{c}-0.378^{* * *} \\
(-5.486)\end{array}$ & $\begin{array}{c}0.018^{* *} \\
(2.076)\end{array}$ & $\begin{array}{c}0.018^{* *} \\
(2.073)\end{array}$ \\
\hline Sales Growth & $\begin{array}{c}0.003^{* * *} \\
(2.968)\end{array}$ & $\begin{array}{c}0.003^{* * *} \\
(2.968)\end{array}$ & $\begin{array}{c}0.000^{* * *} \\
(3.434)\end{array}$ & $\begin{array}{c}0.000^{* * *} \\
(3.430)\end{array}$ \\
\hline Board Size & $\begin{array}{c}-0.118^{* * *} \\
(-6.484)\end{array}$ & $\begin{array}{c}-0.117 * * * \\
(-6.514)\end{array}$ & $\begin{array}{c}-0.004 * * * \\
(-6.319)\end{array}$ & $\begin{array}{c}-0.004 * * * \\
(-6.254)\end{array}$ \\
\hline Board Independence & $\begin{array}{c}-0.703^{* * *} \\
(-4.758)\end{array}$ & $\begin{array}{c}-0.703^{* * *} \\
(-4.769)\end{array}$ & $\begin{array}{c}-0.026^{* *} \\
(-2.306)\end{array}$ & $\begin{array}{c}-0.026^{* *} \\
(-2.299)\end{array}$ \\
\hline Gender & $\begin{array}{l}0.179 * \\
(1.913)\end{array}$ & $\begin{array}{l}0.178^{*} \\
(1.891)\end{array}$ & $\begin{array}{c}-0.054 * * * \\
(-4.458)\end{array}$ & $\begin{array}{c}-0.054 * * * \\
(-4.473)\end{array}$ \\
\hline Average Time on Board & $\begin{array}{c}-0.019 * * * \\
(-8.314)\end{array}$ & $\begin{array}{c}-0.019 * * * \\
(-8.288)\end{array}$ & $\begin{array}{c}0.009 * * * \\
(11.258)\end{array}$ & $\begin{array}{c}0.009 * * * \\
(11.232)\end{array}$ \\
\hline CEO Duality & $\begin{array}{c}-0.052 \\
(-0.860)\end{array}$ & $\begin{array}{c}-0.052 \\
(-0.858)\end{array}$ & $\begin{array}{c}0.007 \\
(1.073)\end{array}$ & $\begin{array}{c}0.007 \\
(1.076)\end{array}$ \\
\hline Legal Expertise & $\begin{array}{c}-0.083 * * * \\
(-3.901)\end{array}$ & $\begin{array}{c}-0.082^{* * * *} \\
(-3.882)\end{array}$ & $\begin{array}{c}0.001 \\
(0.385)\end{array}$ & $\begin{array}{c}0.001 \\
(0.437)\end{array}$ \\
\hline Foreign Background & $\begin{array}{c}0.049 * * \\
(2.082)\end{array}$ & $\begin{array}{c}0.049 * * \\
(2.085)\end{array}$ & $\begin{array}{c}-0.031 * * * \\
(-11.206)\end{array}$ & $\begin{array}{c}-0.031 * * * \\
(-11.236)\end{array}$ \\
\hline Financial Expertise & $\begin{array}{c}-0.072^{* * *} \\
(-2.889)\end{array}$ & $\begin{array}{c}-0.072^{* * *} \\
(-2.876)\end{array}$ & $\begin{array}{c}-0.017 * * \\
(-2.329)\end{array}$ & $\begin{array}{c}-0.017 * * \\
(-2.311)\end{array}$ \\
\hline Constant & $\begin{array}{c}-0.245 \\
(-0.938) \\
\end{array}$ & $\begin{array}{c}-0.250 \\
(-0.954) \\
\end{array}$ & $\begin{array}{c}-0.986 * * * \\
(-14.069) \\
\end{array}$ & $\begin{array}{c}-0.986 * * * \\
(-14.052) \\
\end{array}$ \\
\hline Industry, Country, and Year Fixed Effects & Yes & Yes & Yes & Yes \\
\hline $\mathrm{R}^{2}$ & 0.181 & 0.181 & 0.263 & 0.263 \\
\hline Observations & 92681 & 92681 & 90454 & 90454 \\
\hline
\end{tabular}




\section{Table 11: Military Directors and Performance, Controlling for Frontline Experience}

This table presents the estimated impacts of military directors on firm performance while controlling for frontline experience. No. of Frontline Directors is the number of military directors who possess frontline experience in Panel A, and Percentage of Frontline is the number of military directors that possess frontline experience over the total number of military directors, in Panel B. Frontline experience is identified using the name of the role played by the director when in the military. The dependent variable is either Tobin's Q or ROA. Our key variable of interest is either Military Director Ratio, which is the ratio of military directors to board size, or Military Director Dummy, which is an indicator that equals one if a firm has at least one military director and zero otherwise. For detailed variable definitions, please refer to Appendix 1. Robust standard errors are clustered at the country level and $t$-statistics are in brackets. ${ }^{* * *},{ }^{* *}$ and $*$ denote significance levels of $1 \%, 5 \%$ and $10 \%$ respectively.

\begin{tabular}{|c|c|c|c|c|}
\hline & \multicolumn{2}{|c|}{ Tobin's Q } & \multicolumn{2}{|c|}{$\mathrm{ROA}$} \\
\hline & (1) & (2) & (3) & (4) \\
\hline \multicolumn{5}{|l|}{ Panel A: } \\
\hline Military Director Ratio & $\begin{array}{l}-0.364^{*} \\
(-1.756)\end{array}$ & & $\begin{array}{c}-0.018 \\
(-1.025)\end{array}$ & \\
\hline Military Director Dummy & & $\begin{array}{c}-0.058^{* *} \\
(-2.355)\end{array}$ & & $\begin{array}{c}-0.006 * * * \\
(-2.832)\end{array}$ \\
\hline No. of Frontline Directors & $\begin{array}{c}-0.013 \\
(-0.777)\end{array}$ & $\begin{array}{c}-0.007 \\
(-0.361)\end{array}$ & $\begin{array}{c}-0.000 \\
(-0.157)\end{array}$ & $\begin{array}{c}0.002 \\
(0.920)\end{array}$ \\
\hline Constant and Controls & Yes & Yes & Yes & Yes \\
\hline Industry, Country, and Year Fixed Effects & Yes & Yes & Yes & Yes \\
\hline $\mathrm{R} 2$ & 0.181 & 0.181 & 0.260 & 0.260 \\
\hline Observations & 93697 & 93697 & 91460 & 91460 \\
\hline \multicolumn{5}{|l|}{ Panel B: } \\
\hline Military Director Ratio & $\begin{array}{c}-0.457 * * \\
(-2.315)\end{array}$ & & $\begin{array}{c}-0.014 \\
(-0.856)\end{array}$ & \\
\hline Military Director Dummy & & $\begin{array}{c}-0.078 * * * \\
(-3.184)\end{array}$ & & $\begin{array}{c}-0.006 * * \\
(-2.410)\end{array}$ \\
\hline Percentage of Frontline & $\begin{array}{c}0.016 \\
(0.954)\end{array}$ & $\begin{array}{c}0.036 \\
(1.551)\end{array}$ & $\begin{array}{c}-0.002 \\
(-0.729)\end{array}$ & $\begin{array}{c}0.002 \\
(0.540)\end{array}$ \\
\hline Constant and Controls & Yes & Yes & Yes & Yes \\
\hline Industry, Country, and Year Fixed Effects & Yes & Yes & Yes & Yes \\
\hline $\mathrm{R} 2$ & 0.181 & 0.181 & 0.260 & 0.260 \\
\hline Observations & 93697 & 93697 & 91460 & 91460 \\
\hline
\end{tabular}




\section{Table 12: Military Directors and Firm Policies}

This table presents the results of regressing firm Leverage on military directors. Leverage is the ratio of total liabilities to total assets. Our key variable of interest is either Military Director Ratio, which is the ratio of military directors to board size, or Military Director Dummy, which is an indicator that equals one if a firm has at least one military director sitting on its board and zero otherwise. Market Capitalization is the natural logarithm of stock market capitalization. PPE is the ratio of property, plant and equipment to total assets. Sales Growth is three-year average growth rate of the net sales. Board Size is the total number of board directors on the board. Board Independence is the ratio of non-executive directors to board size in year $t$. Gender is the ratio of male directors to board size. Average Time on Board is the average tenure of all the directors on the board. CEO Duality is a dummy variable that equals one if a firm's CEO is also the chairman of the board. Robust standard errors are clustered at the country level and $t$-statistics are in brackets. ${ }^{* * *},{ }^{* *}$ and $*$ denote significance levels of $1 \%, 5 \%$ and $10 \%$ respectively.

\begin{tabular}{lcc}
\hline & $(1)$ & $(2)$ \\
& Leverage & Leverage \\
\hline Military Director Ratio & $0.0580^{* *}$ & \\
Military Director Dummy & $(2.58)$ & $0.0118^{* * *}$ \\
Market Capitalization & & $(2.89)$ \\
& & $-0.0054^{* *}$ \\
PPE & $-0.0054^{* *}$ & $(-2.41)$ \\
& $(-2.38)^{* * *}$ & $0.1266^{* * *}$ \\
Sales Growth & $0.1266^{* *}$ & $(10.32)$ \\
& $(10.32)$ & -0.0001 \\
Board Size & -0.0001 & $(-1.47)$ \\
& $(-1.47)$ & $0.0125^{* * *}$ \\
Board Independence & $0.0127^{* * *}$ & $(4.83)$ \\
Gender & $(4.96)$ & $0.0770^{* * *}$ \\
Average Time on Board & $0.0772^{* * *}$ & $(4.96)$ \\
CEO Duality & $(5.00)$ & $-0.0359^{*}$ \\
Constant & $-0.0361^{*}$ & $(-1.73)$ \\
& $(-1.74)$ & $-0.0056^{* * *}$ \\
\hline Industry Fixed Effects & $-0.0056^{* * *}$ & $(-5.57)$ \\
Country Fixed Effects & $(-5.59)$ & $0.0181^{* * *}$ \\
Year Fixed Effects & $0.0182^{* * *}$ & $(6.93)$ \\
Cluster & $(6.96)$ & $0.2648^{* * *}$ \\
R ${ }^{2}$ Observations & $0.2621^{* * *}$ & $(8.22)$ \\
\hline & $(8.08)$ & YES \\
YES & YES \\
YES & 0.188 \\
& YES & 93705 \\
\hline
\end{tabular}




\section{Table 13: Military Directors and Firm Policy, Lagged Difference Model}

This table shows the results for military directors against firm leverage, obtained from a lagged difference model. The dependent variable is the change in the value of Leverage in year $t$. Our key variable of interest is either $\Delta$ Military Director Ratio, the change in the ratio of the number of military directors to board size in year $t-1$, or $\Delta$ Military Director Dummy, the change in the military dummy variable in year $t-1$. Control variables are the same as in Table 6 , but, instead of the levels, we are using the changes in year $t-1$. For detailed variable definitions, see Appendix 1. Robust standard errors are clustered at the country level and $t$-statistics are in brackets. ${ }^{* * *}$, ${ }^{* *}$ and $*$ denote significance levels of $1 \%, 5 \%$ and $10 \%$ respectively.

(1)

$\Delta$ Leverage

$0.109 * * *$

(5.956)

$\Delta$ Military Director Dummy

$\Delta$ Market Capitalization

$\triangle \mathrm{PPE}$

$\Delta$ Sales Growth

$\Delta$ Board Size

$\Delta$ Board Independence

$\Delta$ Gender

$\Delta$ Average Time on Board

$\triangle \mathrm{CEO}$ Duality

Constant

Constant

$\mathrm{R}^{2}$

Observations

$(-1.289)$

0.003

(1.263)

0.041

(2)

$\Delta$ Leverage

$0.014 * * *$

$-0.014 * * *$

$(-8.609)$

$0.129 * * *$

(5.730)

$-0.000$

$(-1.481)$

$0.007 * * *$

$0.043 * * *$

(2.891)

$-0.078^{* * *}$

$(-3.524)$

$-0.001$

$(-1.297)$

0.003

(1.258)

$-0.002 * * *$

$(-4.156)$

0.041

87371 


\section{Appendix 1: Variable Definitions}

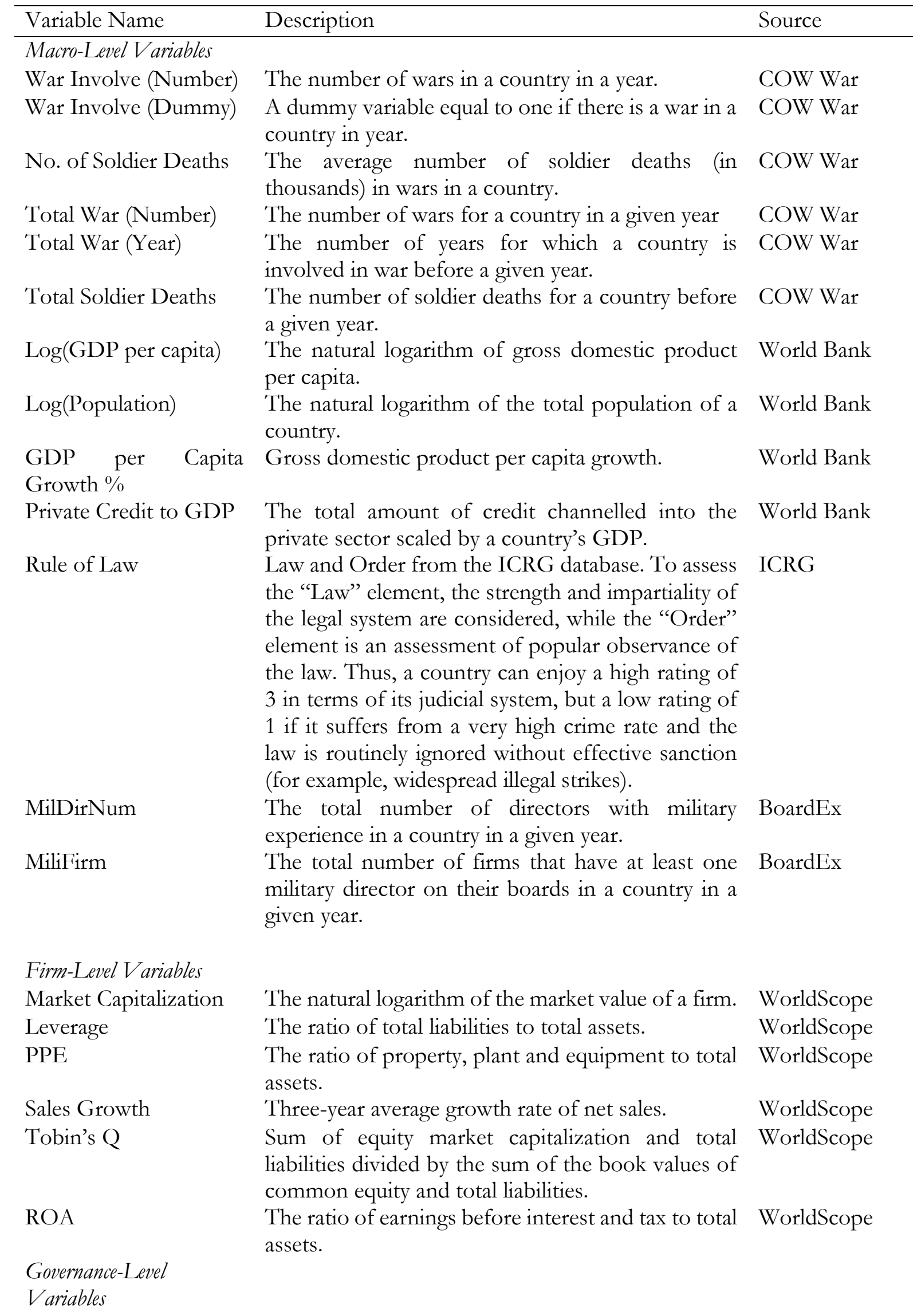


Military Director Ratio Ratio of number of military directors to board size.

BoardEx

Military Director A dummy variable equal to one if a firm has at least

BoardEx

Dummy

one military director on its board, and zero otherwise.

Board Size

Number of board directors on the board in a given

BoardEx year.

Board Independence

The ratio of non-executive directors to board size

BoardEx

Gender in a given year.

The ratio of the number of male directors to board BoardEx

size.

Average Time on The average tenure of the board directors of a firm

BoardEx

Board in a given year.

CEO Duality

Frontline

Foreign Background

An indicator that equals one if a firm's CEO is also

BoardEx the chairman of the board, and zero otherwise.

The ratio of military directors possessing frontline soldier experience to board size. Frontline soldier experience is identified by the name of their role when employed in the military being one of the following: Adjutant General, Admiral, Air Marshall, Air Vice Marshall, Brigadier General, Captain, Chief of Air Staff, Chief of Defence Staff, Chief of General Staff, Chief of Naval Staff, Chief of Operations, Commandant, Commander, Commander-in-Chief, Commanding General, Commanding Officer, Commentator, Deputy Commander, Deputy Commander-in-Chief, Field Marshall, First Lieutenant, First Sea Lord/Chief of Naval Staff, General, Lieutenant, Lieutenant Colonel, Lieutenant Commander, Lieutenant General, Major, Major General, Military Assistant, Military Service, Naval Aviator, Second Lieutenant, Veterinarian, Vice Admiral, Vice Chief of Defence Staff, and Vice Commander.

BoardEx An indicator that equals one if the ratio of directors with foreign backgrounds is above the industry median value and zero otherwise. Foreign background is identified by the nationality of a director being different from the country in which he/she is working.

Financial Expertise

An indicator that equals one if the ratio of directors

BoardEx with financial experience is above the industry median value and zero otherwise. Financial experience is defined as previous experience of working in the financial industry.

Legal Expertise An indicator that equals one if the ratio of directors with legal backgrounds is above the industry median value and zero otherwise. Legal experience is defined as previous experience of working in the legal industry. 


\section{Appendix 2: Summary Statistics by Country}

\begin{tabular}{|c|c|c|c|c|c|c|c|c|c|c|c|}
\hline Country & Firm & War & Country & Firm & War & Country & Firm & War & Country & Firm & War \\
\hline Afghanistan & $\mathrm{N} / \mathrm{A}$ & 7 & Denmark & 31 & $\mathrm{~N} / \mathrm{A}$ & Jersey & 42 & $\mathrm{~N} / \mathrm{A}$ & Puerto Rico & 1 & $\mathrm{~N} / \mathrm{A}$ \\
\hline Algeria & $\mathrm{N} / \mathrm{A}$ & 4 & Dominican Republic & $\mathrm{N} / \mathrm{A}$ & 1 & Jordan & 1 & 4 & Qatar & 3 & $\mathrm{~N} / \mathrm{A}$ \\
\hline Angola & $\mathrm{N} / \mathrm{A}$ & 8 & Ecuador & $\mathrm{N} / \mathrm{A}$ & 1 & Kazakhstan & 1 & $\mathrm{~N} / \mathrm{A}$ & Romania & 1 & 2 \\
\hline Argentina & 12 & 3 & Egypt & 7 & 7 & Kenya & 3 & $\mathrm{~N} / \mathrm{A}$ & Russia & 66 & 11 \\
\hline Armenia & $\mathrm{N} / \mathrm{A}$ & 2 & El Salvador & $\mathrm{N} / \mathrm{A}$ & 2 & Kuwait & 1 & 1 & Rwanda & $\mathrm{N} / \mathrm{A}$ & 6 \\
\hline Australia & 876 & 8 & Eritrea & $\mathrm{N} / \mathrm{A}$ & 2 & Lebanon & $\mathrm{N} / \mathrm{A}$ & 6 & Saudi Arabia & 15 & 2 \\
\hline Austria & 47 & $\mathrm{~N} / \mathrm{A}$ & Ethiopia & $\mathrm{N} / \mathrm{A}$ & 13 & Libya & $\mathrm{N} / \mathrm{A}$ & 3 & Sierra Leone & 1 & $\mathrm{~N} / \mathrm{A}$ \\
\hline Azerbaijan & 1 & 2 & Falkland Islands & 1 & $\mathrm{~N} / \mathrm{A}$ & Luxembourg & 56 & $\mathrm{~N} / \mathrm{A}$ & Singapore & 287 & $\mathrm{~N} / \mathrm{A}$ \\
\hline Bahamas & 2 & $\mathrm{~N} / \mathrm{A}$ & Faroe Islands & 2 & $\mathrm{~N} / \mathrm{A}$ & Macau & 7 & $\mathrm{~N} / \mathrm{A}$ & Slovenia & 1 & $\mathrm{~N} / \mathrm{A}$ \\
\hline Bangladesh & 1 & $\mathrm{~N} / \mathrm{A}$ & Finland & 51 & $\mathrm{~N} / \mathrm{A}$ & Madagascar & 1 & $\mathrm{~N} / \mathrm{A}$ & Somalia & $\mathrm{N} / \mathrm{A}$ & 7 \\
\hline Barbados & 1 & $\mathrm{~N} / \mathrm{A}$ & France & 498 & 21 & Malaysia & 181 & $\mathrm{~N} / \mathrm{A}$ & South Africa & 225 & 5 \\
\hline Belgium & 86 & $\mathrm{~N} / \mathrm{A}$ & Gabon & 1 & $\mathrm{~N} / \mathrm{A}$ & Malta & 4 & $\mathrm{~N} / \mathrm{A}$ & South Korea & 65 & 3 \\
\hline Bermuda & 62 & $\mathrm{~N} / \mathrm{A}$ & Georgia & 1 & 2 & Mauritius & 2 & $\mathrm{~N} / \mathrm{A}$ & Spain & 131 & 2 \\
\hline Bosnia & $\mathrm{N} / \mathrm{A}$ & 2 & Germany & 361 & $\mathrm{~N} / \mathrm{A}$ & Mexico & 50 & $\mathrm{~N} / \mathrm{A}$ & Sri Lanka & $\mathrm{N} / \mathrm{A}$ & 4 \\
\hline Brazil & 74 & $\mathrm{~N} / \mathrm{A}$ & Gibraltar & 4 & $\mathrm{~N} / \mathrm{A}$ & Monaco & 10 & $\mathrm{~N} / \mathrm{A}$ & Sweden & 124 & $\mathrm{~N} / \mathrm{A}$ \\
\hline Burundi & $\mathrm{N} / \mathrm{A}$ & 4 & Greece & 50 & 3 & Mongolia & 2 & 1 & Switzerland & 122 & $\mathrm{~N} / \mathrm{A}$ \\
\hline Cambodia & 1 & 7 & Guatemala & $\mathrm{N} / \mathrm{A}$ & 3 & Morocco & 2 & 4 & Syria & $\mathrm{N} / \mathrm{A}$ & 10 \\
\hline Canada & 946 & 5 & Guernsey & 39 & $\mathrm{~N} / \mathrm{A}$ & Namibia & 1 & $\mathrm{~N} / \mathrm{A}$ & Taiwan & 59 & $\mathrm{~N} / \mathrm{A}$ \\
\hline Cayman Islands & 15 & $\mathrm{~N} / \mathrm{A}$ & Honduras & $\mathrm{N} / \mathrm{A}$ & 1 & Nepal & $\mathrm{N} / \mathrm{A}$ & 2 & Tanzania & 1 & 3 \\
\hline Chad & $\mathrm{N} / \mathrm{A}$ & 7 & Hong Kong & 485 & $\mathrm{~N} / \mathrm{A}$ & Netherlands & 172 & 5 & Thailand & 26 & 5 \\
\hline Channel Islands & 1 & $\mathrm{~N} / \mathrm{A}$ & Hungary & 11 & 2 & New Zealand & 57 & $\mathrm{~N} / \mathrm{A}$ & Turkey & 28 & 7 \\
\hline Chile & 29 & 1 & Iceland & 6 & $\mathrm{~N} / \mathrm{A}$ & Nicaragua & $\mathrm{N} / \mathrm{A}$ & 2 & Uganda & $\mathrm{N} / \mathrm{A}$ & 6 \\
\hline China & 547 & 13 & India & 456 & 10 & Nigeria & 19 & $\mathrm{~N} / \mathrm{A}$ & Ukraine & 4 & $\mathrm{~N} / \mathrm{A}$ \\
\hline Colombia & 12 & 3 & Indonesia & 37 & 12 & Norway & 116 & $\mathrm{~N} / \mathrm{A}$ & United Arab Emirates & 25 & 2 \\
\hline Congo & $\mathrm{N} / \mathrm{A}$ & 9 & Iran & $\mathrm{N} / \mathrm{A}$ & 6 & Oman & 1 & 2 & United Kingdom & 2309 & 16 \\
\hline Costa Rica & $\mathrm{N} / \mathrm{A}$ & 1 & Iraq & $\mathrm{N} / \mathrm{A}$ & 17 & Pakistan & 2 & 8 & United States & 5821 & 22 \\
\hline Cote D'Ivoire & 1 & $\mathrm{~N} / \mathrm{A}$ & Ireland & 114 & $\mathrm{~N} / \mathrm{A}$ & Panama & 1 & $\mathrm{~N} / \mathrm{A}$ & Vietnam & 4 & 12 \\
\hline Croatia & 2 & 4 & Isle of Man & 30 & $\mathrm{~N} / \mathrm{A}$ & Papua New Guinea & 6 & $\mathrm{~N} / \mathrm{A}$ & Virgin Islands (Brit) & 12 & $\mathrm{~N} / \mathrm{A}$ \\
\hline Cuba & $\mathrm{N} / \mathrm{A}$ & 7 & Israel & 144 & 8 & Peru & 6 & 2 & Yemen & $\mathrm{N} / \mathrm{A}$ & 6 \\
\hline Curacao & 2 & $\mathrm{~N} / \mathrm{A}$ & Italy & 110 & $\mathrm{~N} / \mathrm{A}$ & Philippines & 34 & 8 & Zambia & 2 & $\mathrm{~N} / \mathrm{A}$ \\
\hline Cyprus & 20 & 1 & Jamaica & 1 & $\mathrm{~N} / \mathrm{A}$ & Poland & 29 & 3 & Zimbabwe & 1 & 3 \\
\hline
\end{tabular}


